This item was submitted to Loughborough's Research Repository by the author.

Items in Figshare are protected by copyright, with all rights reserved, unless otherwise indicated.

\title{
A retrospective analysis of energy access with a focus on the role of mini- grids
}

PLEASE CITE THE PUBLISHED VERSION

https://doi.org/10.3390/su12051793

PUBLISHER

MDPI AG

VERSION

VoR (Version of Record)

\section{PUBLISHER STATEMENT}

This is an Open Access Article. It is published by MDPI under the Creative Commons Attribution 4.0 International Licence (CC BY 4.0). Full details of this licence are available at: https://creativecommons.org/licenses/by/4.0/

\section{LICENCE}

CC BY 4.0

\section{REPOSITORY RECORD}

Korkovelos, Alexandros, Hisham Zerriffi, Mark Howells, Morgan Bazilian, H-Holger Rogner, and Francesco Fuso Nerini. 2020. "A Retrospective Analysis of Energy Access with a Focus on the Role of Mini-grids". Loughborough University. https://hdl.handle.net/2134/13251479.v1. 


\title{
A Retrospective Analysis of Energy Access with a Focus on the Role of Mini-Grids
}

\author{
Alexandros Korkovelos 1,*(D), Hisham Zerriffi ${ }^{2}$ (D), Mark Howells ${ }^{3,4}$, Morgan Bazilian ${ }^{1,5}$, \\ H-Holger Rogner ${ }^{1,6}$ and Francesco Fuso Nerini 1,5 \\ 1 Department of Energy Technology, Division of Energy Systems, KTH Royal Institute of Technology, \\ Stockholm 11428, Sweden; mbazilian@mines.edu (M.B.); holger.rogner@gmail.com (H.-H.R.); \\ francesco.fusonerini@energy.kth.se (F.F.N.) \\ 2 Department of Forest Resources Management, University of British Columbia, \\ Vancouver, BC V6T 1Z4, Canada; hisham.zerriffi@ubc.ca \\ 3 Department of Geography and Environment, Loughborough University, Leicestershire LE11 3TU, UK; \\ M.I.Howells@lboro.ac.uk \\ 4 Center for Environmental Policy, Imperial College, London SW7 1NE, UK \\ 5 Colorado School of Mines, Golden, CO 80401, USA \\ 6 International Institute for Applied Systems Analysis (IIASA), A-2361 Laxenburg, Austria \\ * Correspondence: alekor@kth.se
}

Received: 30 January 2020; Accepted: 21 February 2020; Published: 27 February 2020

\begin{abstract}
Achieving universal access to electricity by 2030 is a key part of the Agenda for Sustainable Development, and has its own Sustainable Development Goal, SDG 7.1. This is because electricity services are required for almost all aspects of a modern economy, from the cooling of vaccines to irrigation pumping, to manufacturing and running a business. The achievement of SDG 7.1 will require a thoughtful mix of policy, finance, and technology to be designed and implemented at scale. Yet, the pressing need for an electrification ramp-up is not unprecedented. Many countries (now considered "industrialized") faced similar challenges about a century ago. Although the existing literature covers a great deal of power systems evolution, there is a gap around the specific role and impact of small, isolated power systems in the early stages of electricity uptake. In this paper, we provide insights based on the review of the historical electrification efforts in four (now middle and high-income) countries. The drivers and context of electrification efforts in early stages are described. Those focus particularly on the role of dispersed, small-scale generation systems (mini-grids). Our analysis shows that electrification follows four loosely defined phases, namely: pilot projects, technological roll-out, economic expansion, and social scale-up. We report a selection of historical mistakes and advances that offer lessons of striking importance for today's energy access efforts, particularly in regards to the development of mini-grids. We find that today, as historically, multi-stakeholder (e.g., planners, regulators, developers, investors, third party actors) collaboration is key and can help build locally adaptable, economically sustainable and community compatible mini-grids that can accelerate-and lower the societal costs of-universal access to electricity.
\end{abstract}

Keywords: Mini-grids; Electrification; History of power systems; SDG 7

\section{Introduction}

Access to modern energy, and electricity in particular, is an indispensable ingredient of socio-economic progress and well-being [1-5]. Recent estimates indicate that about 70 million people will need to get access to electricity each year, worldwide, if universal electrification is to be achieved by 2030 (authors estimate based on [6,7]). This is a challenging task demanding adequate 
technical, financial, social, and regulatory support. Flexible electrification schemes will need to be put in place and deployed cost-effectively [8].

Many electrification efforts focus on the deployment of large centralized grid systems [9]. Off-grid configurations provide electricity to a minor share of the global population [10]. However, as efforts to achieve the Sustainable Development Goal 7 (SDG 7) gain momentum, decentralized power solutions have the potential to play a key role in achieving universal electricity access. Especially when electricity consumption levels in households are relatively low and/or located far from the grid [8,11-19]. The International Energy Agency (IEA) estimates that about 70\% of rural households, could be electrified via off-grid technologies (both stand-alone and mini-grid) over the next decade or so [20,21]. Although promising, this transition can also increase complexity in the electrification planning process, since off-grid technologies are different to the incumbent central grid and carry their own risks [22]. For example, new —and potentially expensive - technologies (e.g., small-scale renewables with storage) will need to be introduced in places with contentious socio-economic profile raising issues of reliability and affordability [23], or new actors (e.g., start-up entrepreneurs, community groups, etc.) will need to get actively involved and cooperate [24]. Therefore, supporting frameworks will have to be modified or created from scratch to facilitate the sustainable development and operation of such decentralized systems [25-28].

This ongoing power system transformation in the global south is gaining interest and momentum in both academic and policy making communities [5,6,11,29-36]. Yet, it is not unprecedented. Historically such systems have played a pivotal role in the development of national power systems in the global north. Small isolated grids were the spark that lit electricity uptake about a century ago. At the time, technical constraints only allowed for limited power generation and short transmission distances. Eventually, these early decentralized systems slowly expanded and became integrated into or even formed the nucleus for what would become big interconnected networks-commonly referred to as the grid-in most industrialized countries. During this process, many of these systems were completely rebuilt or abandoned due to technical or regulatory mismatches. This caused investments to be lost and assets to be stranded. It also created nationally specific systems.

The general literature on the history of electricity system evolution is rich [9,37-57]. More recently, there has been a wide and growing body of literature on mini-grid based electrification as well $[11,12,15,21,34,58-63]$. Yet, there is a gap linking the two. To date-and to the best of our knowledge- there is no literature elaborating on the development phases of mini-grids, especially from a historical standpoint. What attracted them to some locations (and not others) in the first place? What made them competitive and what did not? What was the role of the local community in their deployment and operation? How did they evolve over time and, if so, what made them scalable? What challenges did they encounter in the process? History and past electrification examples provide a great source of information related to these questions but remain, in our belief, largely untapped.

In an attempt to fill this gap, this paper takes a dive into the history of power systems evolution with a specific focus on mini-grids. In particular, it looks into four high- and middle- income countries from which positive and negative lessons for mini-grids are drawn. By doing so, it also introduces a new conceptual framework of mini-grid development expressed through a four-phase development process and seven common policy questions these phases entail. Methods and materials are described in Section 2. The historical context together with an analysis of common development phases-as identified in the case studies-follows in Section 3. Section 4 contains reflections on the study's findings and key insights. Discussion and conclusions follow after that. Finally, the four case studies are reported in the Appendix A.

Note that in this paper we adopt (and use herein) a more generic definition of mini-grids as "isolated power generation-distribution systems that are used to provide electricity to local communities (power output ranging from kilowatts to multiple megawatts) covering domestic, commercial, and/or industrial demand" [64]. 


\section{Methods and Materials}

This paper was based on integrative literature review [65] over the field of electrification across different times and geographies. This type of review was selected due to the broad reach of our research topic as well as the large volume/variety of information available; reviewing every single scholarly and grey literature on the topic was simply not possible. Therefore, the underlying concept was to collect all potentially relevant literature, review it through the spectrum of our research question and synthesize findings into a conceptual framework that can yield insights regarding the role of mini-grids in achieving energy access. The design and implementation method was conducted in the context of a broader effort funded by the World Bank and supported by key academics and practitioners in the field of electrification. The approach used in the study has several potential limitations. The selected method is subject an un-systematic search strategy, which combines both scholarly and empirical reports and might contribute to inconsistencies. To alleviate that, we have designed and implemented our analysis in three steps.

\subsection{Screening of Extant Literature (Step 1)}

The first step involved traditional desk literature review. That is, the authors conducted an online search for articles and books in major journals and with titles, keywords, or abstracts containing the terms "electrification", "history of electricity", "mini-grids", "off-grid systems", "energy transition", "power system development", "energy access", to name a few. Then, following a "snowballing" effect, literature was expanded to about one hundred publications. Screening for inclusion was based on a) relevance with the research question, b) academic rigor (peer reviewed papers and published books). In addition, the authors elicited input from experts and practitioners in the field of energy access to collect their experience together with any potential grey literature (e.g., reports, documents and archives) relevant to the topic. A first order analysis led to a consultation report examining the historical evolution of power systems in eight countries that is openly available in [64].

\subsection{Analysis of Findings (Step 2)}

Success stories, failures, and trends were then reviewed in more detail by the authors. With a focus on the very early stages of electrification, the authors identified similar patterns across the different cases, time and geographies. These indicated that early electrification occurred via mini-grids, which gradually evolved over four-loosely defined—phases (Section 3). Each phase entailed common challenges to their deployment. For the purposes of this paper, the four case studies of the USA, the UK, Sweden, and China were selected based on literature availability as well as the diversity of technological, social and economic context under which electrification occurred in each case. A concise historical overview of the four phases for each case was then prepared (as presented in the Appendix A). Note that while those four cases are central to the narrative, whenever possible this paper refers to literature on other historical and contemporary examples.

\subsection{Synthesis (Step 3)}

Then, the authors classified common challenges across phases and case studies in the form of seven key questions, very similar to what today's mini-grid developers and/or policy makers face. Finally, a conceptual—and retrospective—analysis was conducted over these questions (Section 4). Using examples from both past and present, parallels were drawn and lessons to follow (or to avoid) were identified. Of course, not all of them are directly transferable elsewhere due to differences in context. These were emphasized and discussed in Section 5.

It should be highlighted that the findings presented in this paper have neither the scope nor the ambition to provide an exhaustive assessment of all geographies as well as sectoral challenges in the field of energy access. Instead, they only represent a deliberate selection of past examples that the authors consider of primary relevance for the development of profitable, affordable (to consumers and 
government) and technically sustainable mini-grid systems that might cater to the needs of today's diverse communities seeking access to electricity. Of course, these are not the only examples, but this paper can only cover a fraction. An expansion of the geographical coverage and diversity of case studies is highly recommended in future work.

\section{A review of Past Electrification Efforts}

\subsection{A Chronology of Power Systems Development}

The era of power systems development began in the second half of the 19th century. In several parts of the world, electricity brought excitement and opportunity, its uptake characterized by disruptive innovation, and was the effect of many contributing factors [66]. These were systemically endogenous such as technology advancements, innovation, and/or entrepreneurial drive $[37,66]$. There were also exogenous factors, driven by economic principles, legislative support and barriers, institutional structures, historical contingencies and various geographical aspects [37,66].

In many cases, mini-grids served as a crucial starting point for the development of national power systems. Areas with vigorous socioeconomic activity were the early adopters. Urban centers and productive facilities saw electricity as a great means of improving common operations, efficiency and profit. The Pearl Street Station in New York (1882) was the first electric utility and also a mini-grid. It operated a thermal power plant fired by coal and provided electricity to about 80 different customers for illumination services via a short direct current (DC) distribution system [37].

From New York and Chicago in the United States of America (USA) to Godalming, London, and Berlin in Europe, and Kimberly in South Africa, small electricity generation and distribution units started to emerge and operate almost simultaneously in cities [37]. In other locations, similar systems were built to power industrial loads (e.g., in Sweden [39,67]) or to serve other productive activities (e.g., agriculture and livestock processing in rural USA [51]). A common aspect amongst these early adopters was high demand density (urban areas and industrial facilities) or low-cost supply (such as hydro sites).

During the first decades, technical limitations were a major restricting factor. Generation units were small and transmitting electricity had physical limits that kept distribution local. Electricity demand was also immature and limited to few services, mainly public lighting. Moreover, electric power systems were (and still are) capital intensive. That is, the maximization of electricity output, sales, and thus revenues have been key to the cost recovery of initial investment costs. Early on, these systems were trying to improve load factor and economic performance (see for example the rapid expansion of hydropower in eastern California during the early 20th century [53]).

Over time, technology improved. Larger generators could be built (taking advantage of economies of scale) and electricity could be transmitted over longer distances $[37,53,55]$. At the same time, demand diversified and increased, and policy and regulatory regimes were stabilized. These factors resulted in the emergence of centralized utilities (either privately or publicly owned) $[40,55,68]$. Typically, mini-grids either became integrated with one another, forming the nucleus of a larger centralized system or were absorbed by a larger grid system as this expanded $[37,40,68]$. To this end, one should not neglect the natural monopoly aspect of electricity distribution, which has had a considerable impact [55] throughout the evolution of power systems.

However, this process was not always smooth. Technically, a lack of coordination often resulted in isolated mini-grids using different frequencies and voltage levels (e.g., UK [40,48,69-71]). This made their integration in a central grid a challenging and costly issue. Economically, upfront and maintenance costs were simply too high to justify interconnection, particularly for dispersed, low density population centers (e.g., in Alaska [41] or in rural areas of the continental United States [51]). Institutionally, competing business and institutional interests, as these systems began to overlap, resulted in unfair competition and in significant stranded assets (e.g., UK $[69,70])$. Nevertheless, over 
time, the increasing variety of power plants, loads and control nodes created today's extensive and complex grid network(s).

\subsection{Phases of Electrification}

Electrification processes are case and context specific and embody the technical, scientific, economic, political and organizational resources of society that exist at the time of their construction $[37,66]$. Nevertheless, similar patterns emerged. The historical review suggests that electrification occurred in four loosely defined phases across the cases studied.

Phase 1 is characterized by small innovative pilot projects which, supported by new business models, demonstrate the potential of new technologies. Phase 2 consists of the technology roll-out to anchor customers who can pay a premium for access to certain electricity services and provide proof of the economic viability and range of applications of electric power. Phase 3 is the economic expansion of mini-grid towards bigger-and usually interconnected-networks that leverage economies of scale and reach areas where the economic opportunity stimulates further development. Finally, Phase 4 is characterized by the social scale-up, in which public actors step in, regulate and supplement the market so as to achieve electrification to the 'last mile'.

These phases generally occurred in sequence, with bigger systems overtaking smaller ones as electrification progressed. However, changing circumstances can result in these no longer being necessarily sequential anymore nor resulting eventually in integrated grid systems. A key difference is that historically these phases existed in a complete "greenfield" situation with no electric power system. Today, these phases are still relevant for mini-grid developments supplementing existing grid systems usually serving some of the population. Significant progress in electrification has, for example, been achieved through the economic expansion or social scale-up (phases 3 and 4) of mini-grid systems rather than the grid in several countries (e.g., Kenya, Rwanda, Bangladesh, Myanmar and Sri Lanka) [23]. Nevertheless, each phase presents some general characteristics and challenges that are highlighted in the following paragraphs.

\subsubsection{Phase 1-Pilot Projects}

Electrification started with experimental pilot projects. These were undertaken by early adopters and developers convinced of the projects' economic potential. In 1878 arc lights lit up parts of Chicago [57], while in 1879 a small distribution and lighting network was set up in New York city, following Edison's commercialization of the light-bulb [38]. In 1881, the streets of Godalming in the UK were given electric lighting, powered by a hydro-generator [40]. Thereafter, in 1882 the Pearl Street Harbour power station in New York, powered a first of a kind low voltage DC distribution network covering an area of roughly half a square kilometer [38]. A year later, Princess Street in Dublin was illuminated [52]. The first Swedish DC facility was operated in Härnösand in 1885 [39]. In the 1890s, the Zhang Garden of Shanghai was electrified by the Shanghai Electric Company [72]. Each of these were experimental. They showed the promise of a new era of possibility-and profit.

\subsubsection{Phase 2-Technological Roll out}

After the initial experimental phase, numerous inventions and innovative ideas set the ground for a rapid roll out of electricity related technologies. The technical nature of these early systems (DC based distribution, small generating capacity [38]) and limited demand (primarily lighting to begin [37,40]) led early systems to consist of small-scale generation and highly localized distribution. In this phase, governmental support was low or absent and development was driven primarily by private initiative. By the end of the 19th century, the technological innovation that made this roll out possible included, for instance, Edison's three-wire system (1883) and the introduction of storage batteries, notably improving the system's technical and economic efficiency [37]. Shortly after that, the commercial development of the AC technology by Westinghouse and Tesla in 1885 [38], fundamentally changed the distribution network and provided electricity at high voltage and low current. The polyphase 
motor and transmission system (1889) reduced transmission costs and expanded the capacity limits that allowed longer interconnections [38]. That paved the way for the Deptford experiment in London by Ferranti (1890), which extended the limits of transmittable power [42]. All of these innovations led to new, cost-effective supply chains for electricity and demand growth.

In parallel, the technological roll out phase involved the active participation of critical anchor customers who would pay a premium for this new energy service. Grosvenor Gallery in London's West End (1883) is one example [40]. The private gallery would willingly pay a premium for having a small generator lighting up its exhibition room to attract the attention of its elite visitors. Nearby shopkeepers followed shortly after, with electricity seen as a symbol of prestige. Similar examples are evident also in other countries between the 19th and early 20th century. In China, banks, theatres, tea houses, and restaurants were the early adopters of electricity [73]. It is important to note that all these early systems started as isolated mini-grids with the generation technology (initially mostly hydro-, coal- and later diesel-powered) located close to the points of demand (cities, commercial nodes and industrial sites).

\subsubsection{Phase 3-Economic Expansion}

Following the roll out phase, technology and operational know-how was transferred from one society/place to another with entrepreneurs, financiers but also inventors contributing to the expansion of mini-grids. In turn, this expansion triggered the involvement of a growing number of stakeholders such as government agencies, professional societies, educational institutions and, of course, businesses. The increased number of stakeholders made energy planning more complex and played an important role on mini-grid's role and growth-as noted below.

Economic expansion led to the increase of electricity demand in industrializing countries [17]. That happened mostly in urban centers and productivity "hot spots". Similar patterns were observed, for example, in New York [74], Paris [75], London [40], Berlin [37], and Chicago [37] where mini-grids expanded in response to a growing demand for energy. In some cases competition was fierce. London by 1913 had proportionately the largest number of privately owned generators of any other big city with seventy generating stations and sixty-five utilities in operation [37]. In other areas, natural monopolies emerged [76]. In Chicago, Samuel Insull leveraged new technologies and economies of scale, gradually absorbing most of the smaller mini-grids in the city [55]. Non-generation assets (e.g., distribution network) remained but generating capacities were replaced by rotary convertors that could step-down the voltage from the larger system. Industry co-evolved with electricity purchases from nearby generators, or by relocating operations to resource rich areas (e.g., coal mines, big rivers) [43]. From 1885 onwards, this occurred (amongst other places) in the USA (California [53] and Alaska [77]) and Sweden [39]. In Sweden, industries started selling the surplus of their mini-grid generation to nearby consumers in order to increase profit [39]. The marginal cost of this excess electricity was low.

\subsubsection{Phase $4-$ Social Scale-up}

The social scale-up phase was characterized by increased public sector involvement in the development of power systems either directly through parastatal utilities or through policies and incentives and/or regulation for the private sector. In some cases, the governments' goal was to ensure extensive access to electricity services due to the benefits to be obtained (e.g., stimulating further agricultural economic growth in the USA [51]); in others the goal was to avoid the potentially damaging impacts of market failure of private monopolies (e.g., UK [40] or Sweden [39]). In the early 20th century, Sweden was one of the first countries in which coalitions between the private (energy intensive industries) and public sector (municipalities) were formed in order to overcome the high investment costs in power infrastructure [39].

In the USA, social pressure in accordance with political will to boost economic activity, triggered electrification efforts, with the establishment of the Rural Electrification Administration (REA) in 1935. The financial and technical support of the REA arguably incentivized the development and 
rapid growth of several non-profit cooperatives that actively supported (through the development of mini-grids at first) electrification efforts in rural areas of the USA. With an estimated budget of 321 million USD and in 5 years, 1.7 million farms were electrified-more than in the previous fifty years of electrification [51]. The UK took a different approach, by progressively nationalizing the power system first with the Electricity Act of 1926 and then with the Electricity Act of 1947 [40,71]. In that effort, the UK government developed the national transmission system by integrating the over 600 isolated mini-grids that were present on the UK territory [70]. Finally, in China, the strong policy-making authority along with substantial financial support from government was very conductive to scaling up the electrification process [44]. Although the central grid expansion was substantial, mini-grids also played a pivotal role in electrifying areas where grid extension was not an economically viable solution.

\section{Connecting Historical with Present Role of Mini-Grids in Electrification Efforts}

In all the cases studied, policy and regulation took different shapes and touched on different issues. In some cases, acts and laws were conductive to the successful deployment of mini-grids. Meanwhile, in some others, they raised big barriers. Some key aspects of regulatory frameworks identified in the case studies are listed below.

\section{System ownership and operation}

Regulation played a key role in defining the ownership and operation mode of mini-grids [40]. In some cases, private ownership was initially promoted to attract investments and to avoid first of a kind technology risks for the state [40]. This is particularly true in the UK where a BOOT (build, own, operate, and transfer) scheme was used in order to allow private ownership and operation of a power system, but only for a limited amount of time, in order to protect customers from the excesses of monopoly power [40,71]. It should also be noted that private ownership in some cases (e.g., early installations in the USA), came about not because it was explicitly designed by regulators to attract investment but because there was no guiding hand and investors saw an opportunity. In other cases, (e.g., China [44]), mini-grid systems were predominantly under public control. Finally, mixed schemes have also been employed under public-private partnerships (e.g., Sweden [39]).

\section{Competition}

Certain regulatory frameworks were progressively adopted in order to allow for market competition aiming to restrict private monopoly power and avoid high end-user prices. For instance, in the UK, regulation was in place so as to limit mini-grid operations regionally or temporally [40]. In contrast, in Sweden the power supplier constructing a distribution line was given monopoly over the areas served by that line [39]. However, prior to the construction of that line, a distribution agreement was required between the mini-grid operator and its customers. Supply companies were competing for customers by lowering end-user prices. In the USA, competition followed the rules of a liberated market; early mini-grid developers leveraged economies of scale, reduced production costs and expanded rapidly over competition within a few years (e.g., Chicago) [55].

\section{End-user prices}

In the past, regulation had a key role in harmonizing tariffs and leveling end-user prices between densely populated urban areas and low-density rural areas [51]. Regulation was often introduced with the emergence of national grids [40,51]. In the UK and the USA, pre-paid arrangements and recovery of connection costs via tariffs promoted grid vs mini-grid based electricity in the 1930s [40,51]. In China $[44,78]$ the government subsidized electricity tariffs for the rural population by cross subsidies and direct funding of mini-grids.

\section{Technical, safety and environmental standards}

Proper regulation and technical (including reliability), safety and environmental standards gradually gained critical importance in the development of power systems, especially when isolated mini-grids started becoming integrated to create the main national system [79]. In Sweden, technical standards for the interconnection of mini-grids were developed since the early stages [39]. On the other hand, failure or delay in setting common standards resulted in systems operating under varying 
frequencies and voltages. For example, in the beginning of the 20th century, the electrical systems in London were operating under 10 different frequencies and 24 distribution voltage levels [48]. Note: safety and environmental standards were not always absent in the early stages. In London for example, safety regulations for the construction of power lines were evident in the early 20th century (e.g., Deptford power station) [40,71].

Despite the complexity and differences in their historical development, we see some value in attempting a summary of common challenges faced by early mini-grids, in the form of seven policy questions. These include how one might:

- Attract initial electricity suppliers and/or initiate (and design) demonstration projects?

- Ensure scalability and reducing roll-out risks?

- Ensure sustainable business models and supply chains?

- Develop local and adaptable solutions?

- Cope with change?

- Minimize initial investment requirements and long-term operating costs?

- Ensure reliability of supply and environmental security?

All of them remain crucial for mini-grid developers and electrification policy makers today. In the following paragraphs, a retrospective analysis for each one of them is presented by drawing parallels between then and now.

\subsection{Attracting Initial Suppliers and/or Initiating (and Designing) Demonstration Projects}

Many countries currently struggle to attract pilot mini-grid projects (e.g., Bangladesh [28], Senegal [80]) as investors have been deterred due to the lack of a clear policy and regulatory framework regarding e.g., licensing, tariff structures, future integration with the national grid [81], profit repatriation, governance and risk mitigation strategies for investors among others [82]. In Uganda, for example, commercial banks provide only short-term (seven-year maturity), high-interest loans [83]; this acts as an additional barrier to mini-grid developers, whose time to overall profitability usually surpasses this timeframe ( $>7$ years [84]).

Our historical review shows that early mini-grid demonstration projects flourished when developed with the promise of longer-term business opportunity. In the USA for example, rapid industrialization and the socio-economic shifts it affected, created demand for modern, low-cost forms of energy and self-sufficiency that attracted the interest of both innovative engineers and investors [37,57]. They operated with minimal constraining regulation $[55,57]$ within the context of the laws of those days. Paying anchor customers and ambitious developers perceived themselves to be exercising their freedom [40] as this new market developed. Many entrepreneurs perceived the electricity sector as a new business opportunity $[45,53,55]$. This, in turn, attracted new investment that boosted the country's economy. Competition promoted technological innovation and led to the development of new, more efficient power systems [37,42].

Similarly, nowadays creating an environment conducive to attract new investment, technology and business models is essential for mini-grids to flourish [25-28,85]. That has happened successfully in countries like Nepal [86] and Cambodia $[18,87]$ where clear regulations and government support helped the uptake of mini-grid solutions. However, in other cases private entrepreneurs providing energy access with mini-grids acted without central support (or even competing with public authorities, e.g., in Brazil [88]). In fact, many of the innovations occurring today (e.g., development of various technology-enabled pay-as-you-go models [26]) are being driven by entrepreneurs acting often as small start-ups [89]—often at the margins of the existing system. In those cases, lack of centralized alternatives for certain areas enabled other systems to flourish. However, a lack of coordination and central support can result in slowed adoption, and reduce the possibility to scale-up private mini-grids (see next section). 


\subsection{Ensuring Scalability and Reducing Roll-Out Risks}

Today, in most low -and middle- income countries mini-grids still remain in the pilot phase [90]. The roll-out risks are significant, including fee collection failure, resource availability and price volatility, construction or operational failures, social unacceptance, theft, vandalism, energy resource intermittency or force majeure risks (mud slides, severe storms etc.) [91]. The customer base usually consists of households with low consumption and ability to pay. Thus, mini-grid failures have been reported, for example, in Nigeria [92], Ghana, Kenya, Tanzania, and Malawi, causing projects to be stalled, shelved, appropriated, or abandoned [93]. In Thailand, more than half of the solar mini-grid systems deployed to electrify more than 50,000 households have been rendered unusable due to poor maintenance [94].

Historically, mini-grid deployment efforts faced different risks in different phases. During the pilot and roll out phases, first of a kind technologies and business models were demonstrated by trial projects. Their viability was dependent on few early customers willing to pay a price that covered the producer's full costs and profit. Prices were usually set in freely negotiated power purchase agreements (PPAs) [40,53]. Allowing the market to determine optimal prices (rather than fixed tariffs) allowed investors to inject more money into system expansion. During the economic scale-up phase, more complex business models evolved [56] to secure investment paybacks. In Sweden, electricity from mini-grids increased the productivity and profits of industries and other enterprises [39], spurring the economy in nearby communities, which in turn become new potential customers for electricity. Mini-grids also allowed competition at the local level, which kept tariffs low and increasing receptivity to new technologies. Following that, investments were encouraged by focused government support for the social scale-up phase. In China for instance, access to electricity was seen as a way to boost productivity and rural economic development [44]. This gradual electrification for productive uses through mini-grids allowed demand to grow in parallel with the ability of rural populations to pay for additional services. The development of demand for electricity and functional distribution systems made it easier to later extending and updating the main grid.

The challenge to electrification today as in the past is finding the balance between regulating without hamstringing the scale-up phase for mini-grids. Regulation is needed to recognize the role of private mini-grids in national systems, and to ensure that private mini-grids can possibly be absorbed in the future in a centralized system. That includes technical standards and the possibility for the private investors to have a continued income when that happens. On the other hand, over-regulation can hamper scale-up driven by the private sector. This occurred in London in the 1880s and 1890s, when extensive regulation hampered economic scale-up. Mini-grid developers were unable to cope, still being in the critical make-or-break pilot, roll-out, or economic scale-up phase. It is therefore essential to develop policies and regulations that create a level yet flexible planning field for mini-grid developers.

\subsection{Ensuring Sustainable Business Models and Supply Chains}

Historically, the development of mini-grids (and their supply chains) required profitability. Whether publicly or privately owned, systems that were not profitable (or at least cost recovering) eventually went out of business (for the private sector, see London's Holborn station suspension in 1896 [36]) or suffered from operational difficulties requiring subsidies with no option to expand or become sustainable (e.g., bankrupt [95] or loss-making [96-99] public utilities).

Similarly, today in some areas (with high population density, productive activities, low cost resources etc.), business models can already cost effectively set up mini-grids and sell the electricity to consumers $[18,78,88,100]$. However, there are also cases in which sustainable business models were not found, especially in cases of low coordination and support with the central system (e.g., Madagascar [101], Burkina Faso, Guinea, Mali, Senegal and Uganda) [102]. In those cases, typically, centrally set flat electricity costs lowered the competitiveness of mini-grids in rural areas. In fact, the levelized costs of electricity (LCOE) may vary significantly depending on location, population density and local energy costs $[8,11,12,34,103]$. On average, LCOEs in rural and isolated areas are 
higher than in high-density urban areas. This is true of both mini-grids and of grid extension. So, while costs are generally higher, mini-grid LCOEs can be lower than extending the grid. In recent times, as in history, high electricity costs did not stop consumers when the energy services provided were very valuable (as for businesses and productive uses) or provided services at lower costs than existing solutions. For instance, several companies in Sub-Saharan Africa are now selling millions of solar-powered off-grid systems with little to no subsidy [29,104]. In areas where financial factors alone are not able to justify the investment in electrification, the local and national government can play a key role by setting supporting schemes for the businesses to provide the services. Several approaches exist, for instance (explicit and transparent), cross-subsidization of electricity costs, tax breaks, capital, and connection or result-based subsidies to name a few [105].

\subsection{Develop Local and Adaptable Solutions}

Historically, early mini-grids were adapted to local settings. The first power generation units in Sweden [39] were developed in sites with abundant water resources. In California, hydropower mini-grids developed in the Sierras, where water was running throughout the year, while oil based mini-grids emerged in areas near the newly discovered oil fields [37,53]. Holborn in the London was based on available coal [40]. Successful examples embraced local situations and co-evolved with those. Similarly, mini-grid projects today need to account for local conditions. Failing this, mini-grids are unlikely to flourish. Take for example the case of a hybrid mini-grid system in Fiji, designed in isolation from local resources, conditions, and skills, the system faced a lot of mismatches, delays, and failures upon installation [106].

Therefore, the availability and/or suitability of natural resources, technologies, supply chains, income, demand, and cultural aspects to energy and environmental regulation all need to be accounted for in the design phase. New computational methods (earth observation, modelling techniques [61,107]) and information technology solutions (real-time monitoring, control and payment methods [108]) allow planners and analysts today to explore quantitatively and qualitatively a broad array of possible scenarios. They can also help improving the ability to measure, monitor and manage production and purchases that have been key to developing dynamic business solutions. Yet, tailored local solutions will have to be balanced against the need for a degree of standardization of either technologies or processes in order to minimize transaction costs and achieve scale to meet the universal access goal.

\subsection{Coping with Change (Grid Competition and Uncertainty)}

Innovation, technological progress, and socioeconomic shifts [109] bring change. One key uncertainty faced by private sector sponsors of mini-grids nowadays in many countries is the extent of central grid expansion, i.e., when and where it will reach the area of a (planned) mini-grid [81]. Having a good anticipation of future grid extensions helps the private sector better prepare for change. When mini-grids are developed in areas which are likely to be accessed by the central grid sometime in the future, these could be designed (at some additional up-front costs) for an eventual integration into the central electricity system. Elsewhere, interim mini-grids with lower standards and costs can be deployed.

A good historical example for this is the case of Illinois. As electricity demand increased in the early 20th century, so did the reach of Insull's centralized grid. Early mini-grids in towns near Chicago would find it difficult to compete. In an effort to avoid stranded assets, they were converted into substations, stepping down high voltage AC sent from the grid [55]. Mini-grid infrastructure could also serve as distributed generation option or to provide reserve capacity. As technology is developing, clear standards for such integration are needed. A more recent example is Cambodia, where regulations have allowed for a flexible scheme whereby private suppliers grant the generation assets to the national utility but retain the distribution licenses after integration of their mini-grids into the national grid [87]. The government provided capital and operational cost subsidies for mini-grid operators, allowing them to continue operate as electricity distributors upon arrival of the grid [87]. 
Finally, schemes could be devised to compensate mini-grid developers' potential sunk costs. In the UK for example (1947), the state absorbed generating assets and liabilities of mini-grid operators upon compensation, in areas where the nationalization scheme forced many local power stations out of business [71].

\subsection{Minimize Initial Investment Requirements and Long-Term Operating Costs}

Today, financing for mini-grids is being made increasingly available in many areas but falls short of what may be needed to meet universal access [110]. Such examples are evident in Indonesia [10], Philippines [111], Kenya [112], and Myanmar [113] to name a few. Harnessing business capital by creating a good business regulatory environment is key. Conditions for harnessing such capital were in place for almost all electrification case studies examined. However subsequent market rules either hampered (as in the case of the UK [40,71]) or accelerated (as in Chicago [55] and California [37]) private investments. More recently, some low- and middle- income countries have seen a flourishing market for private electrification projects. Take the case of Cambodia [87], where a private initiative played a key role in the late 1990s by providing electricity to rural areas in the country's borders with Vietnam, Laos, and Thailand. Electricity was supplied through the private initiative of local entrepreneurs who set up small diesel-based mini-grids to supply a few kWh to the households or businesses in the vicinity [18]. When investment is not provided by the private sector, cooperation with local non-for-profit actors and the population can support electrification projects (as in the case of the USA [51]). For instance, this may include local collectives financing, operating, and maintaining systems. Finally, other complementary governmental policies (such as energy security) can be put in place to achieve complementary objectives to electrification (see case of Alaska [46]).

\subsection{Ensuring Reliability of Supply and Environmental Security}

Newly electrified homes in many low- and middle-income countries have experienced debilitating power outages [114]. Take for example Lagos, Accra and Bujumbura where access reliability is less than $40 \%$ in connected households (note that in this case reliable connection (\%) was defined as the proportion of households with an electricity connection that works "most of the time" or "all of the time") [115]. Modern mini-grids can be designed to offer high levels of supply reliability by utilizing multiple energy sources (hybrid systems), ensuring adequate storage capacity, or both [116,117]. In fact, decentralization of power networks is now perceived in many areas as an effective strategy to increase diversification of indigenous supply and reduce dependency on imports $[63,118,119]$.

Historically, this was (and still is) shown to be of importance in Alaska [120,121]. There, due to the unstable climate conditions and logistical and financial challenges of extending the grid, many remote communities are still electrified by mini-grids. For example, there remain 56 rural communities operated under the Alaska Village Electric Cooperative (AVEC) that receive electricity mainly from diesel (or hybrid diesel/wind) mini-grids [122]. This solution offers higher reliability of supply in most remote areas. Nowadays, renewable-based mini-grids relying on local resources have the potential of further minimizing import resource dependencies [123]. In addition, their local environmental impact can be small [124]. Proper local and/or national regulation is however necessary in order to clearly define technical, safety, and environmental security standards for the sustainable deployment of mini-grids in remote locations [125].

\section{Discussion}

While past examples can provide valuable insights to the posted policy questions, it should be made clear that today's energy access challenges have few notable differences.

First, the majority of the un-electrified population nowadays is located in low income rural areas $[21,126]$. This is unlike most of the historical electrification, when the growing electricity demand was concentrated in industrial and urban settings, places with affluent customers. Of course, even in the historic cases, there was a significant unmet demand and population requiring electricity in rural, 
low income areas but those were usually ignored in favor or urban, wealthier consumers, as is often the case now.

Second, electrification is happening in the context of existing (even if sometimes limited) centralized grid systems with competition between grid and mini-grid affected by economics, geography, demand, institutional structure and other parameters $[10-13,15,127]$. This is more akin to slightly later time periods of electrification (e.g., the Midwest USA in the first half of the last century) rather than the early days [51,55]. Un-electrified areas with a high population density can now bypass or leapfrog the need for isolated systems that were characteristic of early power systems of the turn of the last century $[11,14]$. On the other hand, centralized systems are not necessarily the default solution either. Some areas are suitable for the centralized grid to expand to, but others may find decentralized systems to be a more appropriate choice (based on population density, demand, resources, and distance from grid among others) $[8,15,104,128,129]$.

Third, the distinction between these centralized and mini-grid systems is not fixed over time. Areas that might presently be cost effectively served by mini-grids may later be best served by a centralized grid. It may also be the case that areas that would be most economically served by the grid, simply will not receive grid connection over a long enough timeframe to make mini-grids a viable intermediate option [10,130]. Alternately, mini-grids may (and are) becoming competitive even within an interconnected grid [131] and can serve as supplemental sources of electricity in areas with weak and unreliable grids [132]. Additionally, targeted policies can make grid extension vs mini-grid development financially attractive to private actors and consumers $[33,133,134]$.

Fourth, technologies have matured and become both technical and financially more viable under a range of conditions. Mini-grids today include various AC [135] and DC [136,137] transmission options and a variety of primary energy sources (oil, biomass, hydro, wind, solar, hydrogen, or hybrids among others) $[27,138]$. Monitoring systems [139] allow companies to gather a large amount of data on systems usage, enabling them to refine their business models and technical solutions. Finally, smart grids with improved automation and communication between supply and demand side technologies have enhance their effectiveness [140].

Nevertheless, and despite any contextual differences, the reading of history signals-in our opinion-a few key messages that may help better integrate mini-grids in current planning efforts aiming at achieving universal electricity access. These include the following.

- Mini-grids, regardless of type or size, should be designed to be successful in terms of economics as well as engineering. That is, they should be designed around technologies that best tap into available local resources, ensure sustainable supply chains, and respect local specificities and needs contributing to their profitability and competitiveness. A good practice for mini-grids might involve focusing on productive anchor loads first. Increasing the productivity and profits of local economic activities is a great motivator both for mini-grid developers and end-users. In parallel, economic growth spurs further socio-economic activity in the vicinity, which can create new customers and diversify the business model over time.

- Community involvement and creating a sense of ownership can improve mini-grid functionality in the long run; especially in rural settings. This might require inclusive governance practices and/or an open dialogue upon critical design and operating parameters such as construction, maintenance, expansion, tariffs among other. In parallel, it is apparent that the end users should be eager to access electricity and understand the relation between cost and benefit from getting that service. The challenge is in being able to do so for the large number of communities that would best be served by mini-grids for meeting SDG7 when such processes can be time-consuming and labor intensive.

- Last but not least, it is important to highlight that there is no "one size fits all" solution for successful mini-grids deployment. Best practices may differ as per supporting laws, public vs private ownership, or regulated monopolies versus liberated markets. 
Under this premise, planning authorities must develop electrification master plans that clearly define the role of mini-grids in delivering universal energy access, quantify - to the extent possible- their contribution in the electrification mix and create a roadmap for their integration in the wider energy systems planning in the country/region. Notably, there is a suite of open access tools that can be used to support such activities as indicated by [61].

Public actors (government and/or regulators) must build upon this roadmap and create a clear and conductive policy framework that allows its implementation. This involves creating guidelines around the rules, conditions, and standards under which mini-grids should be developed and operated, including, for example, licensing regimes, tariff regulation, subsidy and cross-subsidy schemes, power-purchase agreements, uncertainty around grid extension and integration, environmental mandates, access to finance (e.g., grants, no-interest loans, impact investment funds, output based aid (OBA) or result based financing (RBF)) to name a few.

In turn, mini-grid developers must pursue innovative solutions (both in terms of technology and business) that provide reliable electricity services and are in alignment with technical, financial, regulatory and social characteristics of the target market, location, community or customer.

Finally, third party actors (international aid, donors) must coordinate and harmonize their efforts under a clear strategic plan and strict mandates (e.g., ensuring service reliability, quality standards, proper use and maintenance, capacity building) for supporting and scaling up mini-grid deployment in a sustainable manner; particularly in areas where neither the private nor the public sector can support immediately (e.g., remote rural communities).

\section{Conclusions}

Despite progress in the last decade, universal electrification still remains a major challenge for many countries today. Decentralized electrification, and mini-grids in particular, have been receiving an ever-increasing amount of attention across the power sector as part of the solution. Although promising, their integration in electrification planning efforts brings higher uncertainty as new players, business model, technical standards and regulations need to be modified or created from scratch. In this paper, we reviewed the history of electrification in order to gain insights on what makes mini-grids an overall sustainable electrification solution.

Our analysis showed that mini-grids were an integral part of power systems since their early days in many countries. Their development was gradual and a result of co-evolution with local demand, available technology and existing policy [24]. Mini-grids played different roles in different geographical and socio-political settings. While some succeeded and some failed, mini-grids have contributed-in one way or another-to the development today's modern electricity network in many countries.

Leveraging on experience from the past, our findings reaffirm that mini-grids can once again play an important role in achieving universal access to electricity today. It is important though that there is a clear and conducive regulatory framework, especially with regards to the role, duties and responsibilities all stakeholders (e.g., developers, government, regulators, planners, investors, aid) involved in the development of modern mini-grids. Notably, our analysis indicates that the private sector, given the right incentives, can play a major role in speeding-up deployment and lowering the societal costs for the achievement of universal access to electricity, by driving innovation and developing locally appropriate business models for mini-grids. Yet, a private-sector only approach will not be able to deliver universal access to electricity, as subsidies and cross-subsidies will most certainly be required at different levels. That is, the role of the public sector is equally important in providing necessary financial support, to ensure customer protection and safeguard equity and inclusion in areas the private sector cannot reach. Similarly, international aid and a social scale-up approach is also needed in some areas where neither private investors nor public utilities cannot support immediately.

Concluding, we hope that the historical review and retrospective analysis presented in this paper offer a new perspective on the role mini-grids can have in current (and future) electrification planning 
efforts, and help to better inform policy aiming at ensuring universal access to affordable, reliable, and modern energy services for all.

Author Contributions: Conceptualization, A.K. and M.H.; Data curation, A.K.; Formal analysis, A.K., H.Z., M.H. and H.-H.R.; Funding acquisition, M.H. and M.B.; Methodology, A.K.; Project administration, M.H. and M.B.; Supervision, M.H., M.B., H.-H.R. and F.F.N.; Validation, A.K.; Writing-original draft, A.K.; Writing-review \& editing, A.K., H.Z., M.H., M.B., H.-H.R and F.F.N. All authors have read and agreed to the published version of the manuscript.

Funding: This research was partially funded by the World Bank under the contract number 1456022 and by the Swedish Center for Smart Grids and Energy Storage (SweGRIDS-ABB) under grant VF-2015-0018.

Acknowledgments: This paper was enriched by findings deriving from a research activity supported by the World Bank (output available online at https://openknowledge.worldbank.org/handle/10986/29023). The latter was supported by email exchanges and personal interaction with key professionals in the field of electrification, from academia, the public and the private sector. That being so, we would like to sincerely thank Jon Exel (The World Bank), Dan Waddle (NRECA), Chris Greacen (Independent Consultant), Liliana Vivanco (The World Bank), Mark O’Malley (University College Dublin), Michael A. Toman (The World Bank), James Knuckles (Independent Consultant), Constantinos Taliotis (Kungliga Tekniska Högskolan), Gabriela Peña Balderrama (Kungliga Tekniska Högskolan \& Universidad Mayor de San Simón) and Ioannis Pappis (Kungliga Tekniska Högskolan), for their generous and insightful contribution to that work. Note that none of these individuals, should be held responsible for any erroneous facts or interpretations presented in this paper. These are solely responsibility of the authors.

Conflicts of Interest: The authors declare no conflict of interest.

\section{Appendix A. Country Case Studies}

The case studies included in this paper are reported in greater detail below; each one presented through the four loosely defined phases of electrification that this paper identified: pilot projects, technological roll-out, economic expansion, and social scale-up.

Appendix A.1. USA

Appendix A.1.1. Phase 1-Pilot Projects

Electrification in the USA started with Edison's invention of the first commercial incandescent light bulb in 1879 [141]. A few years later the first power system (1882), the Pearl Street Station in New York started commercial operation. It was a small generator coupled with a low-voltage direct-current (DC) distribution network covering roughly an area of half square kilometer [38]. Similar systems emerged throughout the USA. In Chicago electricity arrived in 1878 with arc-lights lighting up big public spaces and streets around the city [57]. In 1892, there were twenty small electric-lighting utilities in Chicago producing electricity mostly using small reciprocating engines (e.g., Chicago Edison, operated 2.8 MW and served $~ 5000$ customers) [142]. In California major cities used small coal and oil fueled power generators even by the end of the 19th century [53]. Meanwhile in the countryside, small-scale hydro power was developed near mines, farm communities and small towns [37]. It powered local crafts (sawmills, agro processing), mining and industries (wash out ore, moving belts and gears etc.) [53]. Similarly, in Alaska electricity arrived in the early 1890s, to support productive activities (mining, local merchants) around major cities. An example is Willis Torp's small water mill in Gold Creek river that served small productive loads in the vicinity [143]. Small steam power plants were also introduced in the main urban centers (e.g., Juneau and Anchorage) [77].

Appendix A.1.2. Phase 2-Technological Roll out

The value of electricity started being widely appreciated. After big cities, smaller municipalities developed their own systems. In 1912 the number of municipally power plants was estimated at about 1562, a number that grew to 2581 by 1922 [51]. In parallel, many technological innovation (Edison's three-wire system and batteries (1883), Sprague's motors and multiple unit-system (1895) and Diehl's variable-speed DC motors (1884)) significantly improved the systems' technical and economic efficiency [37]. In addition, the commercial development of alternating current (AC) in 1886, and 
poly-phase motor in 1890, fundamentally changed power distribution; it reduced transmission costs and expanded the capacity (and thus future market share) of AC over DC [37]. Larger systems became possible in terms of generation capacity, transmission distance and loads served (see Niagara Falls, NY in 1895) [37]. In Chicago, Samuel Insull was one of the first to leverage technological advancements and build a big, interconnected and mode efficient electric power system. Insull surmised that economies of scale were the solution to overcome the financial hurdles standing before a more centralized system. Turbogenerators replaced the obsolete, un-scalable reciprocating engines and big AC generating power stations became predominant (Fisk Street Station, world's first modern turbogenerator, 1902). Initially, old small-scale generators would operate alongside with the larger units. This however, caused inefficiency as they were able to serve only a small surrounding area $[37,55]$. Over time, these small decentralized units turned into substations using rotary converters. In the early 1900s most industrial, commercial and residential applications were running on DC power. Rotary converters were commonly used to convert AC to DC before the advent of chemical and solid state rectifiers in the 1930s and 1960s. In California, the increasing electricity demand in big cities, pushed hydropower capacity to expand beyond the rural Sierras. Folsom (American river, 1888), Colgate (Yuba river, 1898), and Nevada City (1895) power plants were built out of private initiative [37]. Similarly, in Alaska 30 hydropower installations with an estimated capacity of 11.5 MW were built by 1908 [144] They powered mining, canning and sawmill businesses [77].
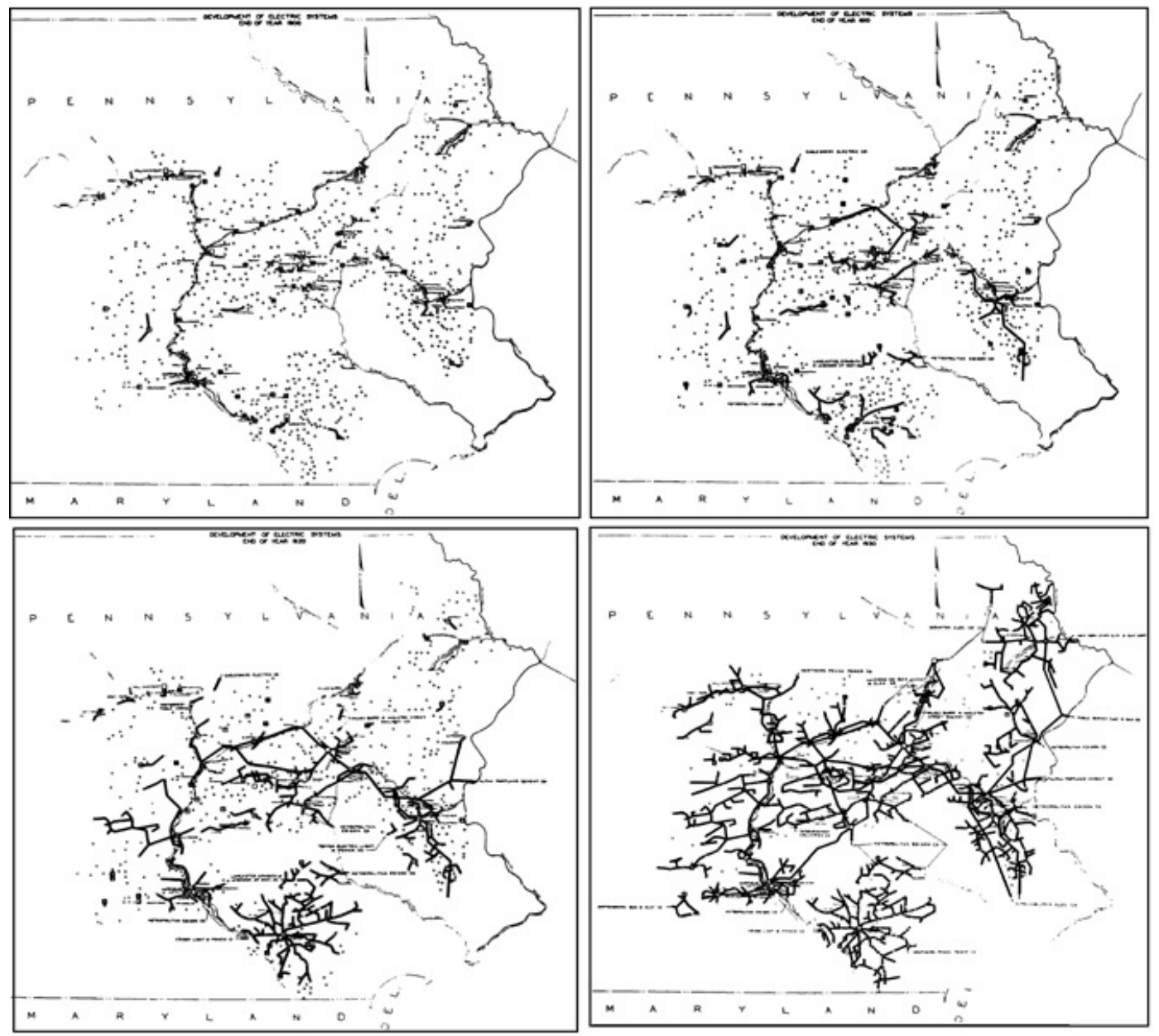

Figure A1. Development of electric power system in Pennsylvania (PP\&L) between 1900 and 1930. The initially local mini-grid systems started getting interconnected as a means of coping with the growing, variable demand and achieving better economic performance. Adopted from [64]; original image from [66]. 
Appendix A.1.3. Phase 3-Economic Expansion

Electricity service expanded and demand diversified. The industrial and commercial loads of the daytime were supplanted in the evening by that of theatres, hotels and restaurants. As those loads and that of residential customers tapered off, the demand of bakeries, dairies, cleaning services, and other nighttime businesses reached a peak [145]. New load had to be first anticipated in timely fashion and then adequately accommodated. This required additional generation capacity and wider distribution network or both. Electricity providers had to find ways of balancing revenue and expenditures by establishing appropriate rates and charges. System planning and forecasting techniques became part of business and guided business strategy and investment. By 1910 the power network in Chicago was one of the most advanced systems in the world [37]. After the city center, Insull's power grid expanded rapidly within 80-120 kilometers [55]. Existing mini-grids in nearby villages and towns, were acquired and turned into substations. By 1923, more than two hundred rural communities had been interconnected over an area of 16,000 square kilometers [37]. Centralized, mass production of electricity lowered electricity prices; in that remarkable 30-year period, the rates charged for power had fallen to half even as the price of the fuel used to make electricity had tripled [55]. In turn, this gave a competitive advantage over decentralized competition and brought new subscriptions (from 5000 in 1892 Insull's grid customers increased to 200,000 in 1910) [55]. In California, the recently invented point-to-point transmission marked an new era of possibility-and profit [53]. By 1914 several hydropower plants and small steam based mini-grids in the area were interconnected under an integrated system serving 1.3 million people over an area of 96,000 square kilometers $[37,53]$. Interconnection improved the load factor of the system and boosted economic performance (thus profitability) [37,53]. In Alaska, economic expansion was moderate and came later. Military presence and operation between 1939-1945 increased electricity demand substantially; the power system was expanded despite material shortages or construction delays due to war (e.g., Eklutna power plant) [46].

\section{Appendix A.1.4. Phase 4-Social Scale-up}

Despite the vigorous expansion of electricity systems in the USA, in 1923 only $2.6 \%$ of farm homes in rural areas had access to electricity compared to $42 \%$ in cities [51]. Private utilities could see high financial hurdles in extending the distribution systems rural areas; after all demand was low and immature to justify their network extension. The push for rural electrification in the USA came as result of social pressure and political will. Rural electrification was surmised as a means of boosting economic activity (mainly expressed through the 'New Deal' program). The task was challenging. Bringing electricity to large areas at reasonable tariffs was an engineering as well as a financial challenge [51]. As a result, the Rural Electrification Administration (REA) was established in 1935 [51]. REA's mission was to use a loan system to financially support states, corporations, individuals, municipalities and co-operative, non-profit associations in order to construct and operate small power plants (mini-grids), transmission and distribution lines and bring electricity to unserved population [51]. It also provided training to engineering and construction firms, in order to engage the private sector in the electrification process. Private sector's enthusiasm quickly waned and turned into opposition; on the contrary several farm organizations and public power entities welcomed the effort and tried to avail themselves of the REA's financial programs [51]. The financial and technical support of REA arguably incentivized the development and rapid growth of several non-profit cooperatives. These cooperatives had a major contribution in the electrification of rural communities. Cooperative staff together with contractors who were trained in rural design and standards, dug the holes, set the poles and strung the wires by hand, supplying their small homemade electrical systems with a couple lights for each house and barn, plus a few small motors or other minimal use appliances [146]. With an estimated budget of 321 million USD-and in 5 years - 1.7 million farms got electrified; that is more that in the previous fifty years of electrification in the USA [51]. Co-operatives, mini-grid systems and strong technical and financial support from the state transformed rural America within a few year. 
Appendix A.2. UK

Appendix A.2.1. Phase 1-Pilot Projects

The UK was at the forefront of scientific experimentation with electricity in the early 18th century. Francis Hawksbee's early static electricity demonstration in London's Royal Academy (1705), Davy Humphry's battery in London's Royal Institutions (1808), Michael Faraday's electromagnetism discoveries in 1820s and Joseph Swan's experiments with the incandescent lamp (1850-60s), are landmarks in the history of electricity. In 1881, the streets of Godalming were lit using hydro power and a dynamo-electric generator [69]. It soon became apparent that electric lighting was competitive gas lighting. Factories and affluent individuals in other cities started deploying small generation units (often dynamos) for lighting [40]. William Siemen's $4.5 \mathrm{~kW}$ steam engine for example, produced power to light 30 incandescent lamps at private property near Tunbridge Wells [40].

Appendix A.2.2. Phase 2-Technological Roll out

Electricity expanded fast. By the beginning of the 20th century (1900) London had proportionally the largest number of privately owned power generators than any other big city [37]. With a growing demand and the promise of higher profits, new and bigger generators were necessary. In 1882 the $200 \mathrm{~kW}$ Holborn power plant was inaugurated in London; it consisted of two "Jumbo" dynamos [38,147]. Electricity was used for lighting. Though gas lighting was still popular and cheap; that is, for the new power plant to be competitive costs should be kept low. At the time price was more important than the quality of service [40]. It was foreseen that economies of scale could lower production costs therefore the Holborn plant needed to expand both in capacity and distribution capacity.

However, erecting pylons on private land and laying cables in public streets required statutory authority. Local authorities were concerned about monopoly abuses of property on the one hand vs having the public bear the potential costs of an untried, first of a kind technology on the other [37]. Debates over power infrastructure development and environmental disruption were common. One regulatory solution was to grant limited franchises for small service areas to avoid costly duplication of distribution. This solution protected both private and public investment concerns to some extent, and reinforced the jurisdictional power of the local authorities. Interestingly, the building of public utilities and municipal cooperatives were also encouraged in the firm belief that public enterprises would compete with private companies. With the Electric Lighting Act of 1882 private companies were eligible to build and operate electricity generation and distribution infrastructures for 21 years [40]. The theory was to have private investors assume the risk of 'first of a kind' technology, with the provision that after a number of years the municipal authorities had the right to buy the companies for the price of the equipment as scrap [37]. This is an earliest application of "build, own, operate transfer" (BOOT) as a regulatory tool for managing the risks and benefits of new technologies. The Act, however, not only reduced private sector interest in the business but also led many early electricity companies to bankruptcy. The Holborn station closed down in 1886 [40].

Despite legal and financial complexities, some successful cases emerged. In 1883 a small AC generator start operating at Grosvenor Gallery. It lit up a few arc-lamps in an art exhibition room and caused excitement to neighbors and nearby shopkeepers [40]. Shortly, wires started hovering over rooftops (bypassing the Act's restrictions), connecting more and more end users willing to pay a premium to connect. 


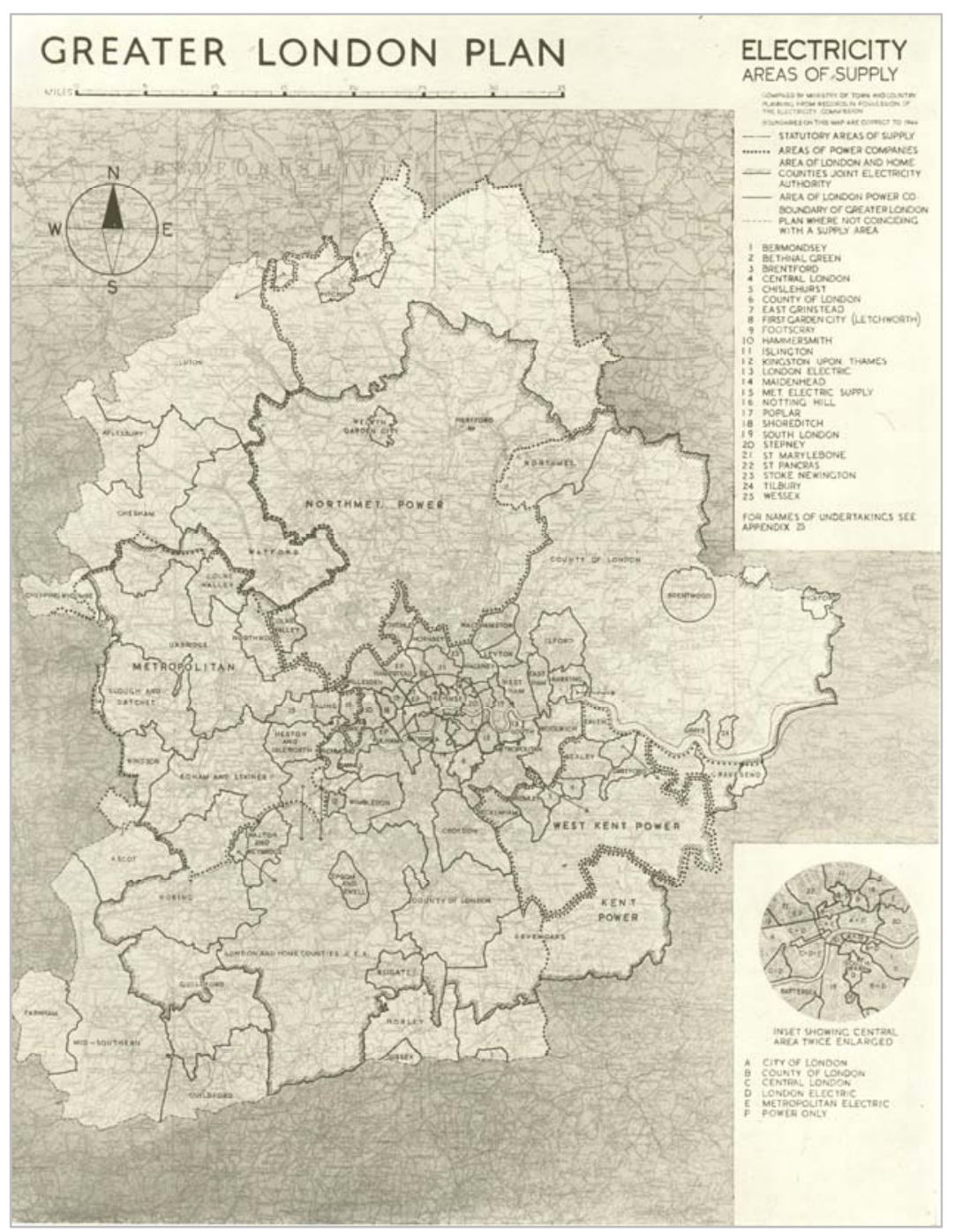

Figure A2. Division of power supply over the greater area of London, 1944. Private companies and municipality utilities were operating their mini-grids in a highly competitive environment. In many cases, this fostered co-operation, especially in the years after WWII due to the dread of an imminent nationalization. Adopted from [64].

\section{Appendix A.2.3. Phase 3-Economic Expansion}

Following Insull's success in Chicago Sebastian Ferranti envisioned an interconnected, centrally powered system in London. His plan was to build two coal-fired generators with $30 \mathrm{MW}$ of total capacity at Deptford [42]. A $10 \mathrm{kV}$ transmission line $[45,148]$ would transfer electricity to the Grosvenor Gallery's station, which had transformed into a substation for electricity distribution in the area. However, due to fears for public safety, the operating license for Deptford granted distribution rights to a much smaller area than initially anticipated. Eventually, Deptford started operations in 1989 with a smaller $938 \mathrm{~kW}$ power generator [42]. Development of universal or regional systems in the UK was discouraged outright or licensed in truncated fashion. Electricity supply subsequently remained local for nearly half a century, with mini-grid isolated systems operated by councils or small private companies [40]. In 1915, the newly established Electric Power Supply Committee identified more than 600 isolated power systems operating across the country [70]. Their average generating capacity was $3.75 \mathrm{MW}$, in many cases too low to be economically sustainable. To cope with the scattered generation and the multiple standards these systems were operating with, the committee suggested the division of the country into district boards. The boards would take over generation and distribution of electricity 
in their allotted area $[40,69]$. Nevertheless, in 1921, there were still more than 480 authorized suppliers of electricity in the UK operating under unsynchronized voltages and frequencies.

\section{Appendix A.2.4. Phase 4-Social Scale-up}

In 2926, the government passed the Electricity Act aiming at setting a more coherent framework for the synchronization and interconnection of distributed systems. Participating generators could sell to the "Grid" at a price; distributors would buy from the "Grid" and sell to customers. In less than a decade - and at a cost of $£ 27$ million-about 4000 miles of cable were hoisted onto $26,265132 \mathrm{kV}$ pylons reaching the far most parts of the country [40]. Connecting rural communities was required cross-subsidization. This was achieved by increased tariffs for the existing customers; amortized costs (in the tariff) over a number of years for new customers; or pre-paid arrangements with a minimum consumption threshold (100 kWh/year) [40]. Yet the rural electrification rate in 1939 was only about 12\% [40]. After the War, reliable electricity services and exploitation of economies of scale in the UK became an unquestioned policy path [40]. In 1947, 500 power generation and distribution organizations (private companies and/or municipal utilities) went under state control, upon compensation. The compensation cost was estimated at $£ 542$ million. This cover only private companies; existing municipal utilities were not compensated. All generating assets and liabilities were transferred into a single state-controlled body. Distribution and retail was carried out regionally by the fourteen Area Boards [71,149]. The firm nationalization in the UK forced any remaining mini-grid to turn their generators off since they were inefficient and too costly to compete with the big, centralized power plants.

\section{Appendix A.3. Sweden}

\section{Appendix A.3.1. Phase 1-Pilot Projects}

Similar to the USA and the UK, electrification in Sweden started in the late 19th century. The first power generation facility was built in Härnösand (1885); it was a water mill that provided DC electricity for street lighting in the town [150]. Electricity was a sign of social status. Towns and small municipalities started building small isolated generators, usually prompt by the will of a prominent person/group of the community (local elite, bankers, traders, etc.) [39]. Distribution was short serving only a limited number of early adopters [39]. Between 1885 and 1900 about 50 small mini-grids ("elverk") were operating in the country $[39,150]$. At that time, Sweden's coal imports was the main energy resource, thus these systems were primarily coal-fired steam stations [150].

\section{Appendix A.3.2. Phase 2-Technological Roll out}

In Sweden however, more than in the previous cases, it was industrial demand that leverage quickly on the new, promising service of electricity as a means to improve productivity and profit. It is evident that in the end of 1885, industrial sites had installed almost double the number of incandescent lamps than in all other parts of society -2233 industrial out of a total of 4432 [39]. The adoption of electric motors followed boosting productivity even more. That, in combination with the energy intensive processes of major Swedish industries (saw mills, mines, manufacturing companies etc.) increased demand for electricity. In response, many industries like pulp and paper industry and in steel, started developing their own generating capacity [39]. Isolated power systems expanded throughout the country in order to serve the growing demand. At the beginning of the twentieth century, the generating capacity in industries alone was about $66 \mathrm{MW}$ [39]. In addition to the industrial capacity, there were close to one hundred municipal electricity plants accounting for about 16 MW [39]. While municipal electricity relied on coal, industrial mini-grids turned into hydropower, which was abundant especially in the norther part of the country. 

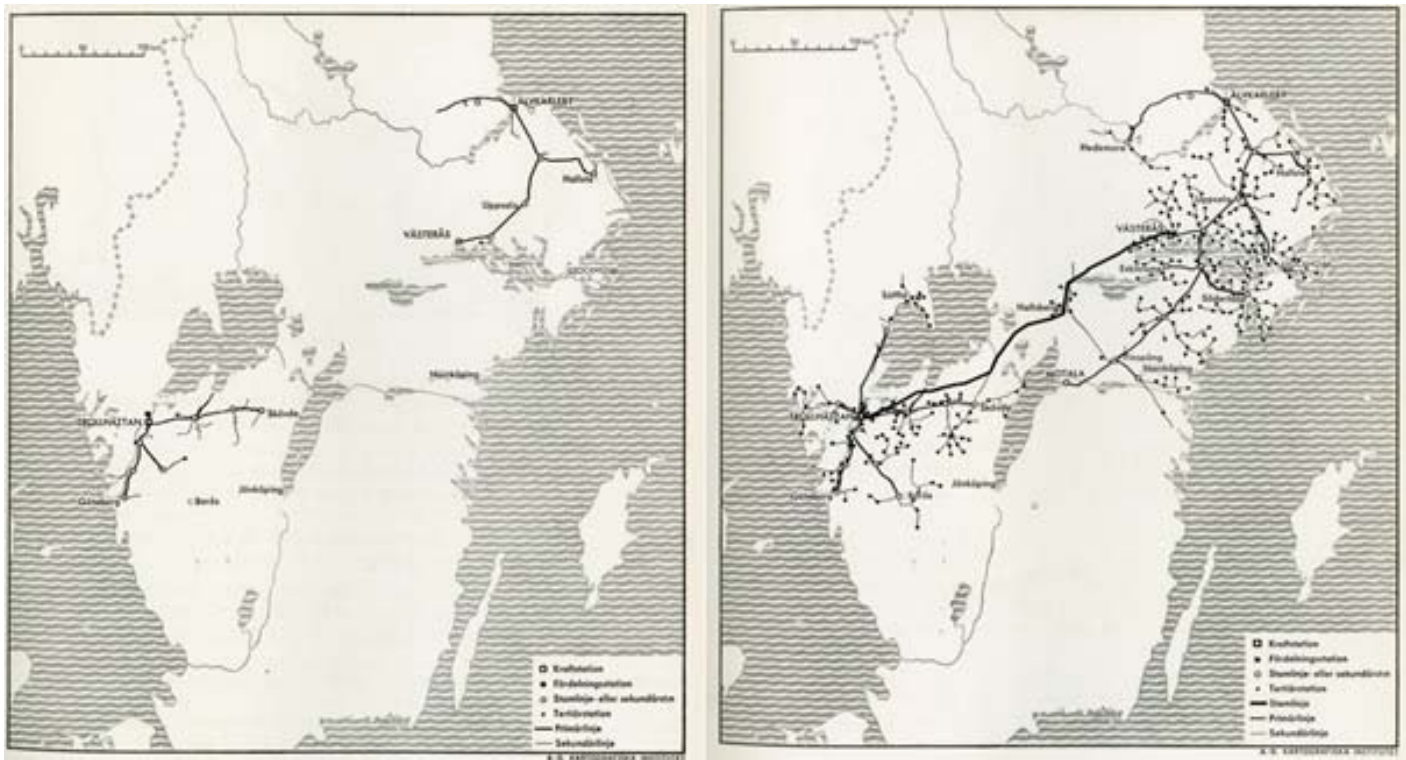

Figure A3. Vattenfall's power system in Southern Sweden as in 1916 (left) and 1922 (right). The figure illustrates how within a few years, mini-grids initially developed to serve industrial loads started expanding in the surrounding area so as to cover a growing residential demand. Inter-connection between existing municipal/industrial mini-grids occurred as an early form of public-private partnership (PPP). Adopted from [64]; original image from [151].

Appendix A.3.3. Phase 3-Economic Expansion

Soon, hydropower became the center of attention for power generation. However, the seasonality of water availability induced variations in electricity production. In an attempt to improved load factors and increase profit, industries sold surplus electricity to nearby customers; these included nearby communities. Households, turned to electricity as a safer, more reliable and cheaper form of energy than commonly used or imported fuels such as wood, lamp oil and kerosene. The gradual introduction of new device in Swedish households (electric irons, radios and later stoves, refrigerators etc.) further stimulated demand in the coming years. Further technological innovations of the time (AC transmission) helped overcome the spatial mismatch between supply and demand of electricity. Hydropower as abundant in the north while residential and commercial electricity consumers in the south. Long distance AC transmission, moved industries closer to the market and where there was plenty of labor. The period between the 1890s and 1920s was the major growth period for industrialized cities in Sweden [39]. Electricity boosted productivity and economic activity but also introduced a new way of life in the Swedish households almost as a side effect [152].

Expansion of generation and distribution required intensive capital. In order to minimize investment risk interested entities formed coalitions. These include municipalities, energy-intensive industries or both (e.g., Kungliga Vattenfallstyrelsen (later Vattenfall), Stora Kopparberg, Stockholms elverk and Uddeholm). This attracted the interest of private investors and led to the formation of several power generation limited companies between 1904-1906 (Sydsvenska kraft-E. ON from 2004-Hemsjö Kraft AB, Yngeredsfors Kraft AB, Stenkvill-Klinte Kraft AB and Kraft AB Gullspång-Munkfors) [39]. Each company was given the right to monopolize the area around its newly built distribution lines [39]. However, the construction of a distribution line required a prior service agreement between the power company and its customer (small industries, commercial stores or households) [39]. This spiked competition between power companies, which were striving to reach maximum customers by improving cost and/or quality of services [39,150]. 
Appendix A.3.4. Phase 4-Social Scale-up

Many disperse municipalities—far from the industrial activity—develop and expanded their own electricity utilities. These were finance either by bank loans or governmental support. In order to minimize construction cost, cooperative distribution associations were formed. They acted at a local level; they built the network themselves, erected poles, mounted wires and gave access to electricity in rural areas. Members were contributing in the form of a collective tariff scheme varying according to the level of electricity consumption. There were 119 cooperatives in 1916 reaching their maximum number of 2401 in 1947 [39].

\section{Appendix A.4. China}

\section{Appendix A.4.1. Phase 1-Pilot Projects}

A few years after electricity lit the streets of big cities in the US and Europe electricity arrived in China as well. The uptake was not as vigorous as in the western mega cities yet few pilot projects emerged in urban areas. In 1892, the Shanghai Electric Co. was formed to provide electricity for lighting in nearby neighborhoods [73]. The first successful example of electric lighting was Zhang Garden in Shanghai; arc lights lit the place for a few hours causing enthusiasm to its elite visitors [72]. Similar to other places electricity was costlier than well-known and popular gas for lighting, yet it was perceived as a safer option. Therefore, it started gaining popularity in areas with foreign activity and entertainment. Banks, theatres, tea houses, restaurants were the early adopters, yet the majority of the population remained un-electrified.

\section{Appendix A.4.2. Phase 2-Technological Roll out}

The early adopters came from productive activities such as mining and agricultural processing. In the 1920s isolated generators started operating around such activities. They were primarily small hydropower units of internal combustion engines powering lighting and motor loads [153]. An example is Jiangsu province where short distribution lines from a coal based mini-grid transferred electricity in the vicinity to support water pumping for irrigation and minor post harvesting activities [44]. By 1949, there just 33 small hydropower stations (of total of 3.6 MW) in rural China with a total installed capacity [44]. The rollout phase in China progress steadily but slowly until the economic liberalization of 1979. It mainly involved the use of local resources, where available. Small-scale hydropower was of primary focus. In 1953, the Small Hydropower agency was established with goal to train engineers that would help actualize the colossal venture of rural electrification. By the end of 1950s, it is estimated that more than 1000 hydropower generation units were build. Low voltage distribution powered lighting, agricultural processing, drainage, irrigation and industrial operations around. Management and operation of these systems was the responsibility of the local government. This policy cultivated a sense of ownership in the shareholders. It attracted more farmers, water agencies and local governments to invest (both in cash and labor) in hydropower deployment. Small hydropower capacity expanded from $150 \mathrm{MW}$ in 1959 to $255 \mathrm{MW}$ in 1963 to $380 \mathrm{MW}$ in 1966 and $729 \mathrm{MW}$ in 1969 and 800 in the late 1970s. In the meantime, as urban centers started to grow, so did the electricity grid therein. Distribution lines of 6-10 kV stretched from the urban centers towards the outskirts, electrifying population in between. By 1979, about 500 million people had already been electrified [44,68,154].

\section{Appendix A.4.3. Phase 3-Economic Expansion}

From 1979 to 1998 the electrification progress observed in China was unprecedented. Decentralized generation-together with large investments on centralized grid—played a major role in providing electricity access to millions. The economic expansion of mini-grid systems was notably benefited by governmental support, which provided funds and financial incentives to promote their development in many rural areas. Policies promoting ownership, facilitating access to loans and foreign investments, allowing revenue streams to local government under lower tax rates and supporting interconnection 
with the main grid when possible, where set in place. During this period about 653 rural counties got electrified via hydropower. Other mini-grid systems (coal or diesel plants) were also built where resources were available in order to achieve greater stability and reliability of supply. It is estimated that by 1998 , mini-grids covered $26.3 \%$ of the rural electricity demand with the remainder coming from the regional or national grid; Small thermal power plants produced $51.1 \%$ of the mini-grid electricity in comparison to $48.9 \%$ from small hydropower [44]. Within 20 years electrification rate in China reached a staggering $97 \%$ [154].

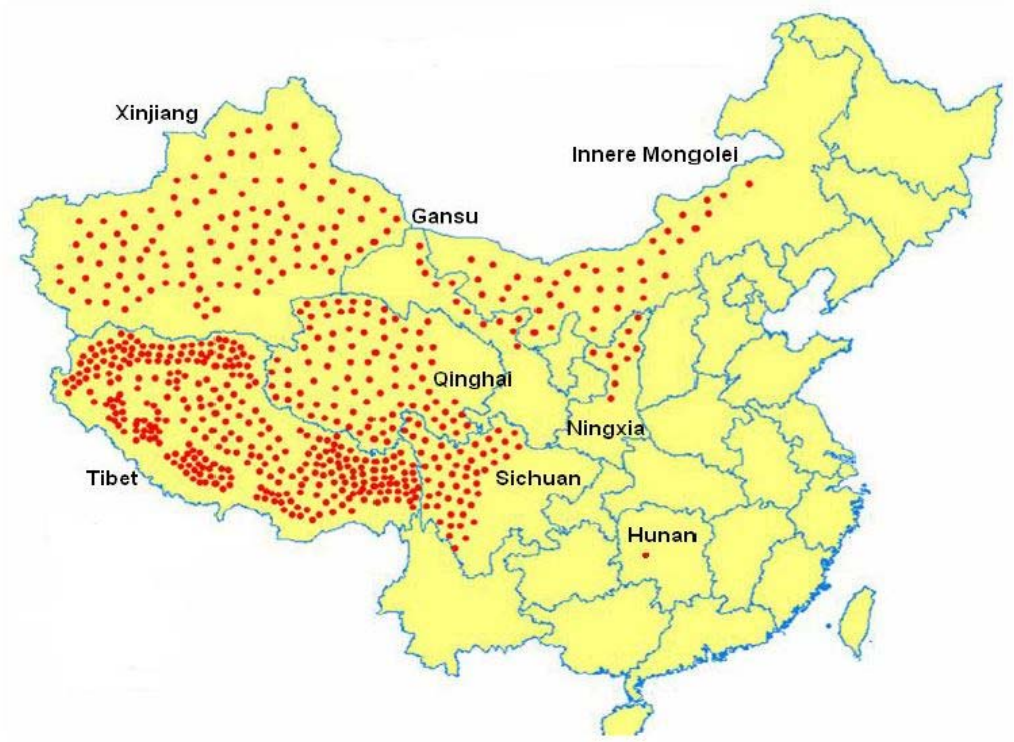

Figure A4. The Township electrification program supported 989 rural townships and villages in western China, electrifying 1.3 million people by means of Photovoltaic (PV), PV/wind hybrid, and small hydro mini-grids. Adopted from [64]; original map by Frank Haugwitz available through [154].

Appendix A.4.4. Phase 4-Social Scale-up

By the end of the century, the electrification gap was still wide. About 8.8 million households ( $\sim 30$ million people) did not have electricity access. These were mainly remote, rural populations. In addition, many rural settings were experiencing frequent shortages; the rural grid network was to a great extend old and insufficient. Rural electricity consumption was limited to few hundred kilowatt-hours per year. The social scale-up of electrification in China included major institutional reforms and extensive renovations. State and regional systems were updated and interconnected to the national grid; electricity tariffs were standardized under a common framework; [44] and several electrification schemes were introduced for the "last mile". These included "Brightness", "Township", "County Hydropower Construction of National Rural Electrification", "Power for All", "Golden Sun" electrification programs and the "China Southern Grid" modernization effort [154]. New, modern and renewable based mini-grid systems (solar, wind, biogas, hybrids etc.) were deployed in areas where grid extension was not an economically viable option (primarily in Xinjiang, Qinghai, Inner Mongolia, Tibet, Gansu, Ningxia, Sichuan provinces) [154]. By 2012 China had achieved universal access to electricity [155].

\section{References and Notes}

1. UN. Report of the World Summit on Sustainable Development; UN: Johannesburg, South Africa, 2002.

2. Modi, V.; McDade, S.; Lallement, D.; Saghir, J. Energy and the Millennium Development Goal; Energy Sector Management Assistance Programme, United Nations Development Programme, UN Millenium Project, and World Bank: New York, NY, USA, 2006. 
3. Parshall, L.; Pillai, D.; Mohan, S.; Sanoh, A.; Modi, V. National electricity planning in settings with low pre-existing grid coverage: Development of a spatial model and case study of Kenya. Energy Policy 2009, 37, 2395-2410. [CrossRef]

4. Fuso Nerini, F.; Tomei, J.; To, L.S.; Bisaga, I.; Parikh, P.; Black, M.; Borrion, A.; Spataru, C.; Broto, V.C.; Anandarajah, G.; et al. Mapping synergies and trade-offs between energy and the Sustainable Development Goals. Nat. Energy 2018, 3, 10-15. [CrossRef]

5. Mulugetta, Y.; Ben Hagan, E.; Kammen, D. Energy access for sustainable development. Environ. Res. Lett. 2019, 14, 020201. [CrossRef]

6. International Energy Agency (IEA). SDG7: Data and Projections 2018; IEA: Paris, France, 2018.

7. International Energy Agency (IEA). World Energy Outlook 2019; IEA: Paris, France, 2019.

8. Mentis, D. Spatially Explicit Electrification Modelling Insights. In Applications, Benefits, Limitations and An Open Tool for Geospatial Electrification Modelling; KTH Royal Institute of Technology: Stockholm, Sweden, 2017; ISBN 978-91-7729-398-9.

9. Mostert, W. Review of Experiences with Rural Electrification Agencies Lessons for Africa; Draft report, European Union Energy Initiative Partnership Dialogue Facility (euei pdf). 2008. Available online: https://www.mostert.dk/pdf/Experiences\%20with\%20Rural\%20Electrification\%20Agencies.pdf (accessed on 8 September 2018).

10. Bloomberg New Energy Finance. 3Q 2018 Off-grid and Mini-grid Market Outlook. 2017. Available online: http://global-climatescope.org/en/off-grid-quarterly/q3-2018/ (accessed on 8 September 2018).

11. Szabó, S.; Bódis, K.; Huld, T.; Moner-Girona, M. Sustainable energy planning: Leapfrogging the energy poverty gap in Africa. Renew. Sustain. Energy Rev. 2013, 28, 500-509. [CrossRef]

12. Szabó, S.; Bódis, K.; Huld, T.; Moner-Girona, M. Energy solutions in rural Africa: Mapping electrification costs of distributed solar and diesel generation versus grid extension. Environ. Res. Lett. 2011, 6, 034002. [CrossRef]

13. Mandelli, S.; Barbieri, J.; Mereu, R.; Colombo, E. Off-grid systems for rural electrification in developing countries: Definitions, classification and a comprehensive literature review. Renew. Sustain. Energy Rev. 2016, 58, 1621-1646. [CrossRef]

14. Levin, T.; Thomas, V.M. Can developing countries leapfrog the centralized electrification paradigm? Energy Sustain. Dev. 2016, 31, 97-107. [CrossRef]

15. Pachauri, S.; van Ruijven, B.J.; Nagai, Y.; Riahi, K.; van Vuuren, D.P.; Brew-Hammond, A.; Nebojsa, N. Pathways to achieve universal household access to modern energy by 2030. Environ. Res. Lett. 2013, 8, 024015. [CrossRef]

16. Pachauri, S.; Rao, N.; Nagai, Y.; Riahi, K. Access to Modern Energy: Assessment and Outlook for Developing and Emerging Regions; IIASA: Laxenburg, Austria, 2012.

17. Rao, N.D.; Pachauri, S. Energy access and living standards: Some observations on recent trends. Environ. Res. Lett. 2017, 12, 025011. [CrossRef]

18. Zerriffi, H. Rural Electrification Strategies for Distributed Generation; Springer: Vancouver, BC, Canada, 2011. [CrossRef]

19. The International Renewable Energy Agency (IRENA). Off-Grid Renewable Energy Systems: Status and Methodological Issues; IRENA: Abu Dhabi, UAE, 2015.

20. International Energy Agency (IEA). World Energy Outlook 2011; IEA: Paris, France, 2011. [CrossRef]

21. The International Energy Agency (IEA). Energy Access Outlook 2017: From Poverty to Prosperity; IEA: Paris, France, 2017. [CrossRef]

22. Riva, F.; Colombo, E.; Piccardi, C. Towards modelling diffusion mechanisms for sustainable off-grid electricity planning. Energy Sustain. Dev. 2019, 52, 11-25. [CrossRef]

23. Korkovelos, A.; Mentis, D.; Bazilian, M.; Howells, M.; Saraj, A.; Fayez Hotaki, S.; Missfeldt-Ringius, F. Supporting Electrification Policy in Fragile States: A Conflict-Adjusted Geospatial Least Cost Approach for Afghanistan. Sustainability 2020, 12, 777. [CrossRef]

24. Feron, S. Sustainability of Off-Grid Photovoltaic Systems for Rural Electrification in Developing Countries: A Review. Sustainability 2016, 8, 1326. [CrossRef]

25. Javadi, F.S.; Rismanchi, B.; Sarraf, M.; Afshar, O.; Saidur, R.; Ping, H.W.; Rahim, N.A. Global policy of rural electrification. Renew. Sustain. Energy Rev. 2013, 19, 402-416. [CrossRef] 
26. Oji, C.; Weber, O. Beyond the Grid Examining Business Models for Delivering Community-Based REPs in Developing Countries; Center of International Governance Innovation: Waterloo, ON, Canada, 2017.

27. Bhattacharyya, S.C. Financing energy access and off-grid electrification: A review of status, options and challenges. Renew. Sustain. Energy Rev. 2013, 20, 462-472. [CrossRef]

28. World Bank Group. Reliable and Affordable Off-Grid Electricity Services for the Poor: Lessons from the World Bank Group Experiences; World Bank Group: Washington, DC, USA, 2016.

29. International Renewable Energy Agency (IRENA). Off-Grid Renewable Energy Solutions to Expand Electricity Access: An Opportunity not to be Missed; IRENA: Abu Dhabi, UAE, 2019.

30. ESMAP. Tracking SDG7|Progress Towards Sustainable Energy 2018. Available online: https://trackingsdg7. esmap.org/ (accessed on 26 October 2018).

31. UNDESA/UNDP. Modelling Tools for Sustainable Development 2016. Available online: https://un-modelling. github.io/electrification-paths-presentation/ (accessed on 10 November 2018).

32. IRENA. Africa 2030: Roadmap for a Renewable Energy Future; IRENA: Abu Dhabi, UAE, 2015. [CrossRef]

33. International Energy Agency (IEA) and the World Bank. Sustainable Energy for All 2017-Progress Toward Sustainable Energy; World Bank: Washington, DC, USA, 2017. [CrossRef]

34. Mentis, D.; Howells, M.; Rogner, H.; Korkovelos, A.; Arderne, C.; Zepeda, E.; Siyal, S.H.; Taliotis, C.; Bazilian, M.; Roo, A.D; et al. Lighting the World: The first application of an open source, spatial electrification tool (OnSSET) on Sub-Saharan Africa. Environ. Res. Lett. 2017, 12. [CrossRef]

35. Akizu, O.; Urkidi, L.; Bueno, G.; Lago, R.; Barcena, I.; Mantxo, M.; Basurko, I.; Lopez-Guede, J.M. Tracing the emerging energy transitions in the Global North and the Global South. Int. J. Hydrogen Energy 2017, 42, 18045-18063. [CrossRef]

36. Palit, D.; Bandyopadhyay, K.R. Rural electricity access in South Asia: Is grid extension the remedy? A critical review. Renew. Sustain. Energy Rev. 2016, 60, 1505-1515. [CrossRef]

37. Hughes, T.P. Networks of Power-Electrification in Western Society, 1880-1930; The John Hopkins University Press: Baltimore, MD, USA, 1983.

38. Andersson, A.E.; Batten, D.F.; Karlsson, C. Knowledge and Industrial Organization; Springer-Verlag: Berlin/Heidelberg, Germany, 1989; ISBN 978-3-642-95597-6.

39. Bladh, M. Electric Stories: Contributions to the History of Electricity in Sweden; Linköping University Electronic Press: Linköping, Sweden, 2011.

40. Weightman, G. Children of Light, How Electricity Changed Britain Forever; Atlantic Books: London, UK, 2011.

41. Villalobos Melendez, A. Energizing Alaska: Electricity Around the State; Institute of Social and Economic Research-University of Alaska: Anchorage, AK, USA, 2012.

42. South Western Electricity Historical Society. Ferranti's Deptford Power Station 2003. Available online: http://emep.worldonline.co.uk/SWEHS/docs/news25su.html (accessed on 16 June 2017).

43. Pain, S. Power through the ages. Nature 2017, 551, S134-S137. [CrossRef]

44. Pan, J.; Peng, W.; Li, M.; Wu, X.; Wan, L.; Zerriffi, H. Rural Electrification in China 1950-2004: Historical Processes and Key Driving Forces; Center for Environmental Science and Policy at Stanford University: Stanford, CA, USA, 2006.

45. Wilson, J.F.; John, F. Ferranti and the Emergence of the British Electrical Industry, 1864-1930; Manchester University Press: Manchester, UK, 1991.

46. ARECA. Northern Lights: A brief history of Alaska's electric Cooperatives; ARECA: Anchorage, AK, USA, 1994.

47. Coopersmith, J. Soviet electrification: The roads not taken. IEEE Technol. Soc. Mag. 1993, 12, 13-20. [CrossRef]

48. Cleveland, C.J. Concise Encyclopedia of History of Energy, 1st ed.; Elsevier: Amsterdam, The Netherlands, 2009.

49. Arakawa, F. History of power systems development in Japan. In Proceedings of the 2007 IEEE Conference on the History of Electric Power, Newark, NJ, USA, 3-5 August 2007; pp. 1-9. [CrossRef]

50. Morton, D.L. Reviewing the History of Electric Power and Electrification. Endeavour 2002, 26, 60-63. [CrossRef]

51. Slattery, H. Rural America Lights Up; National Home Library Foundation: Washington, DC, USA, 1940.

52. Shiel, M. The quiet revolution: The Electrification of Rural Ireland; The O'Brien Press Ltd.: Dublin, Ireland, 1984.

53. Williams, J.C. Otherwise a mere clod: California rural electrification. IEEE Technol. Soc. Mag. 1988, 7, 13-19. [CrossRef]

54. Cunningham, J.J. Brooklyn Electrification: Reflective of National Trends and Practices. IEEE Power Energy Mag. 2016, 14, 105-114. [CrossRef] 
55. McDonald, F. Insull - The rise and fall of a billionaire utility tycoon; Beard Books: Washington, DC, USA, 2004.

56. Tuttle, D.P.; Gulen, G.; Hebner, R.; King, C.W.; Spence, D.B.; Andrade, J.; Wible, J.; Baldick, R.; Duncan, R. The History and Evolution of the US; Electricity Industry: Austin, TX, USA, 2016.

57. Platt, H.L. The Electric City: Energy and the Growth of the Chicago Area, 1880-1930; University of Chicago Press: Chicago, IL, USA, 1991.

58. Ma, S.; Urpelainen, J. Distributed power generation in national rural electrification plans: An international and comparative evaluation. Energy Res. Soc. Sci. 2018, 44, 1-5. [CrossRef]

59. Moner-Girona, M.; Bódis, K.; Huld, T.; Kougias, I.; Szabó, S. Universal access to electricity in Burkina Faso: Scaling-up renewable energy technologies. Environ. Res. Lett. 2016, 11, 084010. [CrossRef]

60. Praene, J.P.; Radanielina, M.H.; Rakotoson, V.R.; Andriamamonjy, A.L.; Sinama, F.; Morau, D.; Rakotondramiarana, H.T. Electricity generation from renewables in Madagascar: Opportunities and projections. Renew. Sustain. Energy Rev. 2017, 76, 1066-1079. [CrossRef]

61. Korkovelos, A.; Khavari, B.; Sahlberg, A.; Howells, M.; Arderne, C. The Role of Open Access Data in Geospatial Electrification Planning and the Achievement of SDG7. An OnSSET-Based Case Study for Malawi. Energies 2019, 12, 1395. [CrossRef]

62. Peters, J.; Sievert, M.; Toman, M.A. Rural electrification through mini-grids: Challenges ahead. Energy Policy 2019, 132, 27-31. [CrossRef]

63. Khodayar, M.E. Rural electrification and expansion planning of off-grid microgrids. Electr. J. 2017, 30, 68-74. [CrossRef]

64. The World Bank. A Retrospective Analysis of the Role of Isolated and Mini-Grids in Power System Development; The World Bank: Washington, DC, USA, 2017.

65. Snyder, H. Literature review as a research methodology: An overview and guidelines. J. Bus. Res. 2019, 104, 333-339. [CrossRef]

66. Bijker, W.E.; Hughes, T.P.; Pinch, T.J. The Social Construction of Technological Systems; The MIT Press: Cambridge, UK; Massachusetts, MA, USA, 1987. [CrossRef]

67. Schon, L. Electricity, technological change and productivity in Swedish industry, 1890-1990. Eur. Rev. Econ. Hist. 2000, 4, 175-194. [CrossRef]

68. Bhattacharyya, S.C.; Ohiare, S. The Chinese Model of Rural Electrification and Electricity Access. Green. Energy Technol. 2013, 116, 105-129. [CrossRef]

69. Hannah, L. Electricity before Nationalisation: A Study of the Development of the Electricity Supply Industry in Britain to 1948; Johns Hopkins University Press: Baltimore, MD, USA, 1979.

70. Jacobson, C.D.; Tarr, J.A. Patterns and policy choises in infrastructure history: The United States, France, and Great Britain. Public Work Manag. Policy 1996, 1, 60-75. [CrossRef]

71. Simmonds, G. Regulation of the UK Electricity Industry; UEA: Bath, UK, 2002.

72. Pang, L. The distorting mirror: Visual modernity in China; University of Hawai'i Press: Honolulu, HI, USA, 2007.

73. Chen, L. The End of the Night-Global Times 2013. Available online: http://www.globaltimes.cn/content/ 813893.shtml (accessed on 16 June 2017).

74. Rees, J. Industrialization and Urbanization in the United States, 1880-1929; Oxford University Press: Oxford, UK, 2016; Volume 1. [CrossRef]

75. Kim, E.; Barles, S. The energy consumption of Paris and its supply areas from the eighteenth century to the present. Reg. Environ. Chang. 2012, 12, 295-310. [CrossRef]

76. Gegax, D.; Nowotny, K. Competition and the Electric Utility Industry: An Evaluation; Yale Journal on Regulation, Volume 10, Issue 1; 1993; Available online: http://digitalcommons.law.yale.edu/yjreg/vol10/iss1/4 (accessed on 16 June 2017).

77. Hollinger, K. The Early Electrification of Anchorage; Natural Resources Branch, U.S. Army Alaska: Anchorage, AK, USA, 2002.

78. Bie, Z.; Lin, Y. An Overview of Rural Electrification in China: History, technology, and emerging trends. IEEE Electrif. Mag. 2015, 3, 36-47. [CrossRef]

79. Brown, A.C. The Structure and progress for Regulation of the Electricity Industry in the United States; Conference on Acting in Time on Energy Policy, Harvard University; 2008; Available online: https://sites.hks.harvard. edu/fs/whogan/Hogan_Elec_r_092508.pdf (accessed on 30 January 2020).

80. Mawhood, R.; Gross, R. Institutional barriers to a 'perfect' policy: A case study of the Senegalese Rural Electrification Plan. Energy Policy 2014, 73, 480-490. [CrossRef] 
81. Greacen, C.; Nsom, S. Rysankova, D. Scaling Up Access to Electricity; The World Bank: Washington, DC, USA, 2015.

82. U.S. Agency for International Development. Challenges and Needs in Financing Mini-Grids. Mini-Grids Support Toolkit 2018. Available online: https://www.usaid.gov/energy/mini-grids/financing (accessed on 15 September 2018).

83. Baldwin, E.; Brass, J.N.; Carley, S.; MacLean, L.M. Electrification and rural development: Issues of scale in distributed generation. Wiley Interdiscip. Rev. Energy Environ. 2015, 4, 196-211. [CrossRef]

84. International Finance Corporation (IFC). Benchmarking Mini-Grid DESCOs-2017 Update 2018; IFC: Washington, DC, USA, 2018.

85. Glemarec, Y. Financing off-grid sustainable energy access for the poor. Energy Policy 2012, 47, 87-93. [CrossRef]

86. Mainali, B.; Silveira, S. Renewable energy markets in rural electrification: Country case Nepal. Energy Sustain. Dev. 2012, 16, 168-178. [CrossRef]

87. Tenenbaum, B.; Greacen, C.; Vaghela, D. Mini-Grids and Arrival of the Main Grid: Lessons from Cambodia, Sri Lanka and Indonesia; Energy Sector Management Assistance Program (ESMAP), World Bank Group, Technical Report; no. 013/18; World Bank Group: Washington, DC, USA, 2017.

88. Fuso Nerini, F.; Howells, M.; Bazilian, M.; Gomez, M.F. Rural electrification options in the Brazilian Amazon. A multi-criteria analysis. Energy Sustain. Dev. 2014, 20, 36-48. [CrossRef]

89. International Finance Corporation (IFC). Off-Grid Solar Market Trends Report 2018; IFC: Washington, DC, USA, 2018.

90. (SEI) SEI. Renewable Energy Mini-Grids: An Alternative Approach to Energy Access in Southern Africa; Stockholm Environment Institute: Stockholm, Sweden, 2016.

91. Manetsgruber, D.; Wagemann, B.; Kondev, B.; Dziergwa, K. Risk Management for mini-grids: A new approach to guide mini-grid deployment, Alliance for Rural Electrification. 2015. Available online: https: //www.ruralelec.org/sites/default/files/risk_management_for_mini-grids_2015_final_web_0.pdf (accessed on 30 January 2020).

92. Offgrid Niregia. 1600 Abandoned Power Projects Keep Nigeria's Rural Folks in Darkness 2017. Available online: http://www.offgridnigeria.com/1600-abandoned-power-projects-keep-nigerias-rural-folks-darkness/ (accessed on 18 August 2018).

93. Ikejemba, E.C.X.; Mpuan, P.B.; Schuur, P.C.; Van Hillegersberg, J. The empirical reality; sustainable management failures of renewable energy projects in Sub-Saharan Africa (part 1 of 2). Renew. Energy 2017, 102, 234-240. [CrossRef]

94. Brass, J.N.; Carley, S.; MacLean, L.M.; Baldwin, E. Power for Development: A Review of Distributed Generation Projects in the Developing World. Annu. Rev. Environ. Resour. 2012, 37, 107-136. [CrossRef]

95. Holson, L.M. California's Largest Utility Files for Bankruptcy; New York Times: New York, NY, USA, 2001.

96. The Economist. More Africans have electricity, but they are using less of it. Electrif. Africa 2017.

97. De Villers, J. Eskom's debt is now more than SA's total budget for health and education. Bus Insid SA 2018.

98. Ng'wanakilala, F. Tanzania seeks \$200m World Bank loan to clear arrears of state utility. Reuters 2017.

99. Tongia, R. The political economy of Indian power sector reforms. In Political Economy of Power Sector Reform; Victor, D.G., Heller, T.C., Eds.; Cambridge University Press: Cambridge, UK, 2007; pp. 109-174. [CrossRef]

100. IRENA. Accelerating Renewable Mini-grid Deployment: A Study on the Philippines; IRENA: Abu Dhabi, UAE, 2017.

101. The World Bank. Evaluation of Rural Electrification Concessions in sub-Saharan Africa: Detailed Case Study_Madagascar; The World Bank: Washington, DC, USA, 2015.

102. Hosier, R.H.; Bazilian, M.; Lemondzhava, T.; Malik, K.; Motohashi, M.; Vilar Ferrenbach, D. Rural Electrification Concessions in Africa: What Does Experience Tell Us? The World Bank: Washington, DC, USA, 2017; pp. 1-96.

103. Fuso Nerini, F.; Broad, O.; Mentis, D.; Welsch, M.; Bazilian, M.; Howells, M. A cost comparison of technology approaches for improving access to electricity services. Energy 2016, 95, 255-265. [CrossRef]

104. Yadav, P.; Heynen, A.P.; Palit, D. Pay-As-You-Go financing: A model for viable and widespread deployment of solar home systems in rural India. Energy Sustain. Dev. 2019, 48, 139-153. [CrossRef]

105. RECP, ARE, REN21. Mini-grid Policy Toolkit: Policy and Business Frameworks for Successful Mini-Grid Roll-outs, 2014. 
106. Dutt, P.K.; MacGill, I. Addressing some issues relating to hybrid mini grid failures in Fiji. In Proceedings of the 2013 IEEE gLOBAL Humanitarian Technology Conference (GHTC), San Jose, CA, USA, 20-23 October 2013; pp. 106-111. [CrossRef]

107. Korkovelos, A.; Mentis, D.; Siyal, S.; Arderne, C.; Rogner, H.; Bazilian, M.; Howells, M.; Beck, H.; Roo, A.D. A Geospatial Assessment of Small-Scale Hydropower Potential in Sub-Saharan Africa. Energies 2018, 11, 3100. [CrossRef]

108. Bhattarai, D.; Corbyn, D.; Ncube, Z.; Njoki, E.; Waters, L. Introduction for Practitioners. Real-time Monitoring, Control and Payment Technologies for Mini-Grids; Practical Action: Rugby, UK, 2016.

109. Shindina, T.; Streimikis, J.; Sukhareva, Y.; Nawrot, Ł. Social and Economic Properties of the Energy Markets. Econ. Sociol. 2018, 11, 334-344. [CrossRef]

110. Mazza, F.; Meattle, C.; Trivedi, S.; Rakhmadi, R.; Haesra, A. Energizing Finance: Understanding the Landscape; Climate Policy Initiative: Vienna, Austria, 2018.

111. Devdiscourse News. Solar Philippines to put USD $15 \mathrm{mn}$ in Microgrid Projects 2018. Available online: https: //www.devdiscourse.com/Article/23818-solar-philippines-to-put-usd-15mn-in-microgrid-projects (accessed on 18 September 2018).

112. The World Bank. World Bank Approves $\$ 150$ Million for Kenya to Provide Solar Energy in Underserved Northeastern Counties 2017. Available online: http://www.worldbank.org/en/news/press-release/2017/07/ 26/world-bank-approves-150-million-for-kenya-to-provide-solar-energy-in-underserved-northeasterncounties (accessed on 7 September 2018).

113. Fairley, P. Off-Grid Electrification Financing Is Failing. IEEE Spectr 2017. Available online: https://spectrum. ieee.org/energywise/green-tech/solar/electrifying-solar-microgrid-financing (accessed on 18 September 2018).

114. Eberhard, A.; Foster, V.; Briceño-Garmendia, C.; Ouedraogo, F.; Camos, D.; Shkaratan, M. Underpowered: The State of the Power Sector in Sub-Saharan Africa; World Bank: Washington, DC, USA, 2008.

115. Gertler, P.J.; Lee, K.; Mushfiq-Mobarak, A. Electricity Reliability and Economic Development in Cities: A Microeconomic Perspective; EEG State-of-Knowledge Paper Series; Oxford Policy Management, Center for Effective Global Action, Energy Institute @ Haas; UC Berkeley: Berkeley, CA, USA, 2017.

116. Guo, S.; Liu, Q.; Sun, J.; Jin, H. A review on the utilization of hybrid renewable energy. Renew. Sustain. Energy Rev. 2018, 91, 1121-1147. [CrossRef]

117. Palatel, A. Isolated Hybrid Energy Systems for Remote Locations. Encycl. Sustain. Technol. 2017, $205-216$. [CrossRef]

118. Yazdanie, M.; Densing, M.; Wokaun, A. The nationwide characterization and modeling of local energy systems: Quantifying the role of decentralized generation and energy resources in future communities. Energy Policy 2018, 118, 516-533. [CrossRef]

119. Liu, J.; Mei, C.; Wang, H.; Shao, W.; Xiang, C. Powering an island system by renewable energy-A feasibility analysis in the Maldives. Appl. Energy 2018, 227, 18-27. [CrossRef]

120. Fay, G.; Villalobos Meléndez, A.; Converse, A. Alaska Energy Statistics 1960-2010 Final Report; UAA: Anchorage, Alaska, 2012.

121. International-U.S. Energy Information Administration (EIA) n.d. Available online: https://www.eia.gov/ beta/international/ (accessed on 27 September 2017).

122. AVEC. Alaska Village Electric Cooperative Annual Report; Alaska Village Electric Cooperative: Anchorage, AK, USA, 2015.

123. Kasperowicz, R.; Pinczyński, M.; Khabdullin, A. Modeling the power of renewable energy sources in the context of classical electricity system transformation. J. Int. Stud. 2017, 10, 264-272. [CrossRef]

124. Yadoo, A.; Cruickshank, H. The role for low carbon electrification technologies in poverty reduction and climate change strategies: A focus on renewable energy mini-grids with case studies in Nepal, Peru and Kenya. Energy Policy 2012, 42, 591-602. [CrossRef]

125. USAID. With What Technical Standards Should Mini-Grids Comply? n.d. Available online: https: //www.usaid.gov/energy/mini-grids/technical-design/standards (accessed on 7 July 2018).

126. Riva, F.; Ahlborg, H.; Hartvigsson, E.; Pachauri, S.; Colombo, E. Electricity access and rural development: Review of complex socio-economic dynamics and causal diagrams for more appropriate energy modelling. Energy Sustain. Dev. 2018, 43, 203-223. [CrossRef]

127. Mentis, D.; Siyal, S.H.; Korkovelos, A.; Howells, M. Estimating the spatially explicit wind generated electricity cost in Africa-A GIS based analysis. Energy Strateg. Rev. 2017, 17. [CrossRef] 
128. Bazilian, M.; Economy, R.; Nussbaumer, P.; Haites, E.; Yumkella, K.K.; Howells, M.; Takada, M.; Rothman, D.S.; Levi, M.A. Beyond Basic Access; Energy Poverty, Oxford University Press: Oxford, UK, 2014; pp. 180-208. [CrossRef]

129. GEA. Global Energy Assessment-Toward a Sustainable Future; GEA: Düsseldorf, Germany, 2012. [CrossRef]

130. Enslev, L.; Mirsal, L.; Winthereik, B.R. Anticipatory infrastructural practices: The coming of electricity in rural Kenya. Energy Res. Soc. Sci. 2018, 44, 130-137. [CrossRef]

131. Tenenbaum, B.; Greacen, C.; Siyambalapitiya, T.; Knuckles, J. From the Bottom Up How Small Power Producers and Mini-Grids Can Deliver Electrification and Renewable Energy in Africa; The World Bank: Washington, DC, USA, 2014. [CrossRef]

132. Zerriffi, H.; Hargadine, S.; Gajarsa, J.; Schumacher, J. Synthesis Report. Decentralized energy Portfolio Review. United States Agency for International Development (USAID), 2016. Available online: https: //pdf.usaid.gov/pdf_docs/PBAAF014.pdf (accessed on 30 January 2020).

133. The World Bank. State of Electricity Access Report 2017; The World Bank: Washington, DC, USA, 2017.

134. Pachauri, S.; Brew-Hammond, A.; Barnes, D.; Bouille, D.; Gitonga, S.; Modi, V.; Prasad, G.; Rath, A. Energy Access for Development. In IIASA CUP Global Energy Assessment-Toward a Sustainable Future; Cambridge University Press: Cambridge, UK; IIASA: New York, NY, USA, 2012; pp. 1401-1458. Available online: http://pure.iiasa.ac.at/id/eprint/10069/ (accessed on 30 January 2020).

135. Watanabe, E.H.; deAraújo Lima, F.K.; daSilva Dias, R.F.; Aredes, M.; Barbosa, P.G.; Lima Barcelos, S.L.S.; Santos, G. Flexible AC Transmission Systems. Power Electron. Handb. 2018, 885-909. [CrossRef]

136. The China Electric Power Research Institute. Steady-State Characteristics of UHVDC Transmission. In the China Electric Power Research Institute, 1st ed.; UHV Transmission Technology; Academic Press: London, UK, 2018; pp. 429-468. [CrossRef]

137. Arcia-Garibaldi, G.; Cruz-Romero, P.; Gómez-Expósito, A. Future power transmission: Visions, technologies and challenges. Renew. Sustain. Energy Rev. 2018, 94, 285-301. [CrossRef]

138. Ram, M.; Child, M.; Aghahosseini, A.; Bogdanov, D.; Lohrmann, A.; Breyer, C. A comparative analysis of electricity generation costs from renewable, fossil fuel and nuclear sources in G20 countries for the period 2015-2030. J. Clean. Prod. 2018, 199, 687-704. [CrossRef]

139. Kasperowicz, R.; Pinczyński, M.; Tiwari, A.; Nawrot, Ł. Reengineering of Electricity Market Monitoring. Econ. Sociol. 2017, 10, 175-188. [CrossRef]

140. Strielkowski, W.; Kasperowicz, R.; Pinczyński, M.; Tiwari, A.; Nawrot, Ł. Social and Economic Implications for the Smart Grids of the Future. Econ. Sociol. 2017, 10, 310-318. [CrossRef]

141. Josephson, M.; Conot, R.E. Thomas Edison|Biography, Inventions \& Facts. Encycl. Br. 2020. Available online: https://www.britannica.com/biography/Thomas-Edison (accessed on 30 January 2020).

142. Schewe, P.F. Most Electrified City. Grid A Journey Through Hear; Our Electrified World Joseph Henry Press: Washington, DC, USA, 2005; pp. 64-89.

143. AELP. An exciting beginning. Alaska Electr Light Power Co 2013. Available online: http://archive.li/MTFdI (accessed on 16 June 2017).

144. United States Department of the Interior-National Park Service. National Register of Historic Places Inventory; United States Federal Government: Washington, DC, USA, 1980.

145. Cunningham, J.J. New York Power|Murphy Institute Blog 2014. Available online: http://murphyinstituteblog. org/2014/12/01/new-york-power/ (accessed on 16 June 2017).

146. In the Beginning—Golden State Power Cooperative. n.d. Available online: https://www.gspower.org/history/ beginning/ (accessed on 16 June 2017).

147. The Electricity Council. Electricity Supply in the UK: A chronology: From the beginnings of the Industry to 31 December 1985; The Electricity Council: London, UK, 1987.

148. Black, R.M.; Robert, M. Science Museum (Great Britain). The History of Electric Wires and Cables; P. Peregrinus in Association with the Science Museum: London, UK, 1983.

149. Katzarov, K. The Pre-Legal Foundations of Nationalisation; Theory National; Springer: Dordrecht, The Netherlands, 1964; pp. 1-19. [CrossRef]

150. Hjulström, F. Sveriges elektrifiering: En Ekonomisk-Geografisk Studie Över Den Elektriska Energiförsörjningens Utveckling; Geographic: Uppsala, Sweden, 1940.

151. Vattenfall. The history and heritage of Vattenf. all n.d. Available online: http://history.vattenfall.com/search/ site/map (accessed on 24 October 2017). 
152. Enflo, K.; Kander, A.; Schön, L. Electrification and energy productivity. Ecol. Econ. 2009, 68, $2808-2817$. [CrossRef]

153. Wright, T. Introduction: Modern Chinese Economic History in a Period. of Change; Chinese Econmy Early Twentieth. Century, Palgrave Macmillan: London, UK, 1992; pp. 1-28. [CrossRef]

154. Niez, A. Electrification Policies. Comp. Study Rural Electrif. Policies Emerg. Econ. 2010, 118.

155. The World Bank. Access to electricity (\% of population)|Data 2017. Available online: http://data.worldbank. org/indicator/EG.ELC.ACCS.ZS (accessed on 16 June 2017).

(C) 2020 by the authors. Licensee MDPI, Basel, Switzerland. This article is an open access article distributed under the terms and conditions of the Creative Commons Attribution (CC BY) license (http://creativecommons.org/licenses/by/4.0/). 